\title{
The Starbuck Essays Of Henry Stommel
}

\author{
Published By \\ Friends Of Starbuck
}

Woods Hole, Massachusetts

1992 
Research and manuscript preparation for The Starbuck Essays were undertaken by Barbara Gaffron. Art Voorhis helped with the historical research. The book was edited and designed by Vicky Cullen.

The Starbuck essays and related material are reprinted with permission of The Enterprise, Falmouth, Massachusetts.

Friends Of Starbuck include:

Anonymous (3), Bob Beardsley, Harry Bryden,

Dolores Chausse, Vicky Cullen and John Waterbury, Barbara Gaffron, Jack Hough, Xin Huang and Lu Ping Zou, Terry and Karen Joyce, Ellen Levy, Mary Ann Lucas, Jim Luyten, John Marshall, Mike McCartney, Gerry Metcalf, Phil Richardson, Roger and Melora Samelson, Ray Schmitt, Susan Tarbell, George Veronis, Gordon and Sue Volkmann, Art and Joanne Voorhis, Sophie Wacongne, Bruce Warren, Doug and Shirley Webb, Chris Wooding and the Woods Hole Oceanographic Institution.

C)1992 Woods Hole Oceanographic Institution

ISBN 1-880224-06-2

Copies of this volume are available for $\$ 15.00$

plus shipping and handling from:

Office of the Research Librarian

Woods Hole Oceanographic Institution

Woods Hole, MA 02543.

Proceeds of the sale of this book augment the Henry Melson Stommel Fund established to endow the atlas collection of the MBL/WHOI Library. 


\section{Foreword}

7 hese essays appeared from time to time over a number of years in The

1 Enterprise, the community newspaper of Falmouth, Massachusetts.

I first encountered "Starbuck" as a youthful editor some forty years ago.

We were early in the cold war. We were in the McCarthy era. Inspired by McCarthy, persons ambitious for attention were going about the country discovering Communists. One of these Paul Reveres of the cold war came to address some gathering on Cape Cod and announced to a startled audience that there were - he knew for a fact-a thousand or more dedicated Communists living on Cape Cod.

A thrill of excitement ran through that part of the community that enjoyed alarms and nourished the idea that there were Russian spies everywhere in the land.

Kicking around the newspaper office was a Rotary Club handbook that listed the members of the several Rotary clubs on the Cape. I counted the names. They added up to a couple of hundred. So I ran an editorial saying that there seemed to be more Communists than Rotarians on Cape Cod.

It was the sort of appeal to the ridiculous that delighted Hank Stommel, and a day or so later he came to me with an appreciative note that was signed "Starbuck." I regret the note isn't preserved. I remember that it was amusing and to the point and that I wished that I had written it.

I had met Hank Stommel, but I did not yet know him. That was the start. Encouraged, I like to think, by my appreciation, the "Starbuck" letters began to arrive at The Enterprise office.

These letters, which I correctly called essays, speak wonderfully for themselves.

Reading the "Starbuck" letters will suggest the pleasure of spending a sociable evening with Hank Stommel over beer and fresh-shucked oysters. I can hear his laughter now.

Bon appétit.

John T. Hough

Publisher, The Enterprise 


\section{Table of Contents}

Henry Stommel ...................................................................................6

"Foolish" Traffic Light Starts Mr. Stommel's Friend To Ponder...................9

Wanted-A New Poet For Shivericks Pond ..............................................10

Falmouth Is A Friendly Place ..............................................................11

Canal Electric's Plume Of Smoke ............................................................12

Don't Write Decade Off-It Has Another Year To Go ................................13

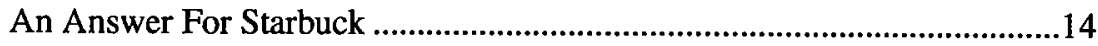

Twenty Years To Go .............................................................................15

The Wanton Jangling Of A Disneyland Bell ..........................................17

"Giant's Ashtray" Was Part Of A Water System ........................................18

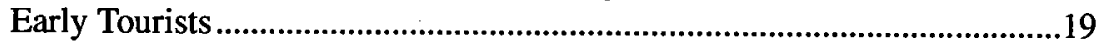

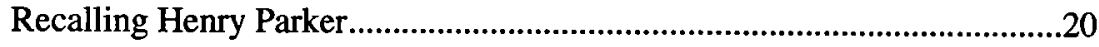

On Behalf Of Those Unexpected Discoveries.........................................21

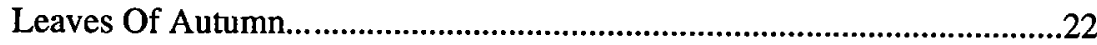

Miraculous Multiplication And Simple Division .......................................24

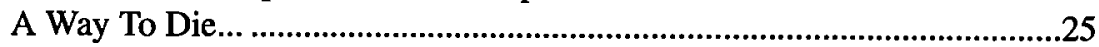

Perhaps A Fresh Start ........................................................................26

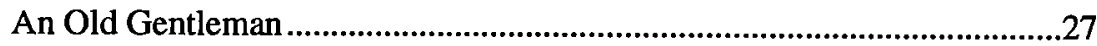

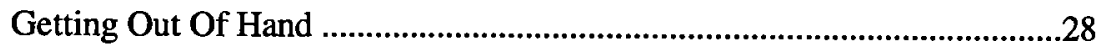

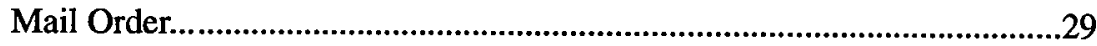

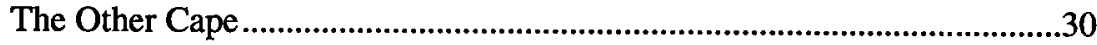

Oh Captain, My Captain .......................................................................31

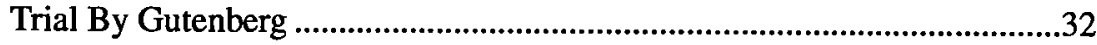

When The Sun Goes Down ...................................................................33

A Man Too Gentle For This World..........................................................34

C.O. Whitman, His Fateful Decisions .......................................................35

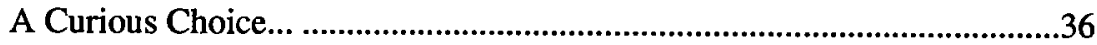

Father Of The Graham Cracker ............................................................37

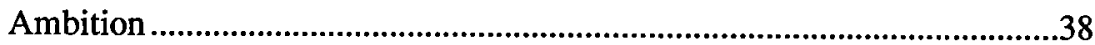

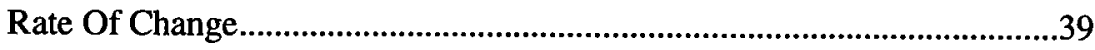

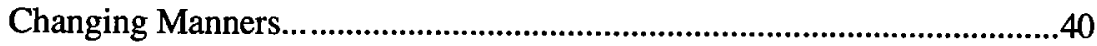

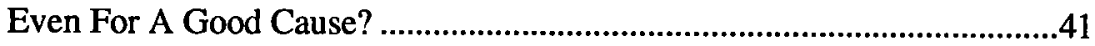

Sailor Of The Old School .......................................................................42

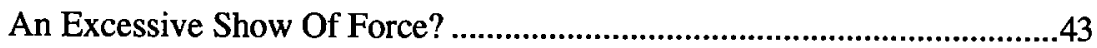

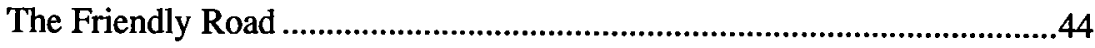

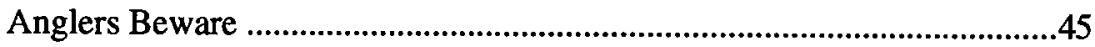

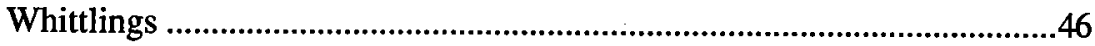

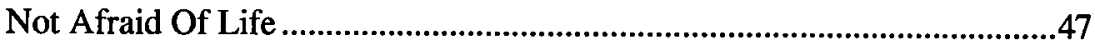

The Woods Hole Mice ..........................................................................48

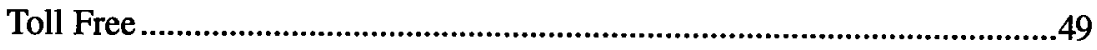

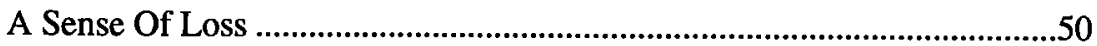

Who Would Have Guessed? ..................................................................51 


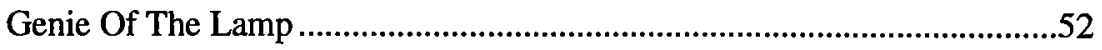

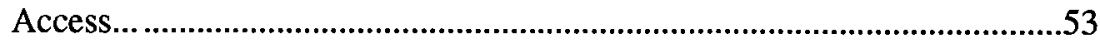

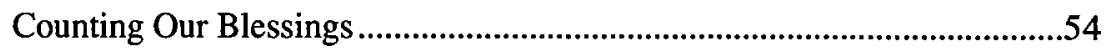

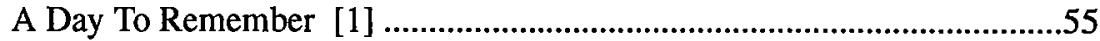

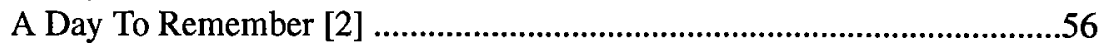

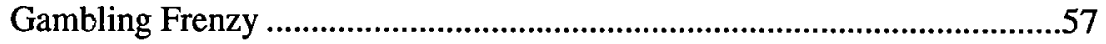

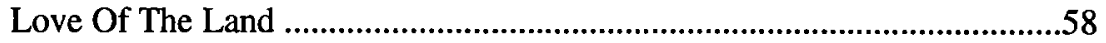

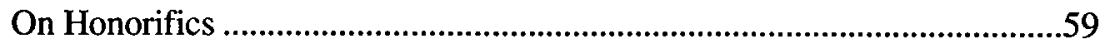

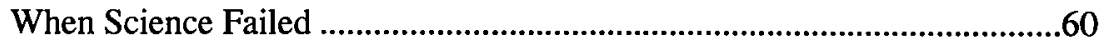

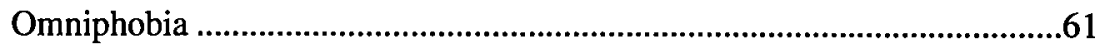

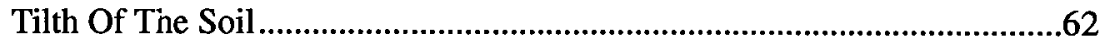

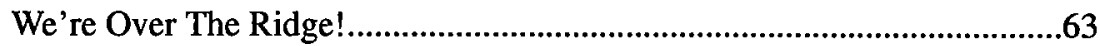

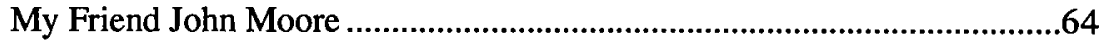

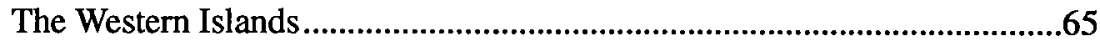

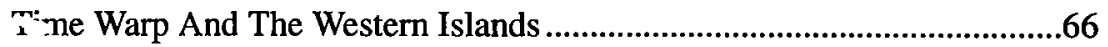

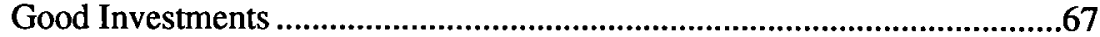

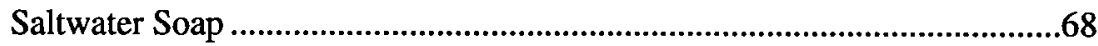

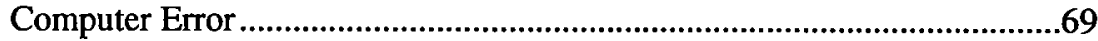

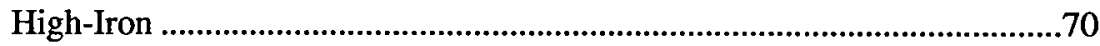

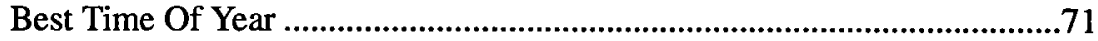

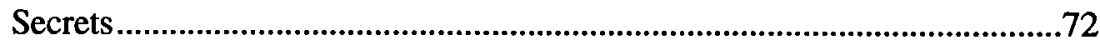

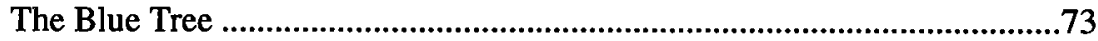

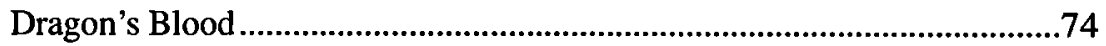

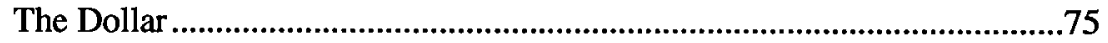

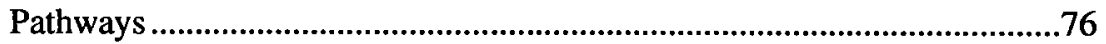

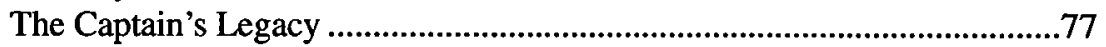

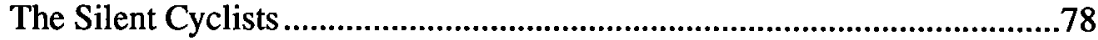

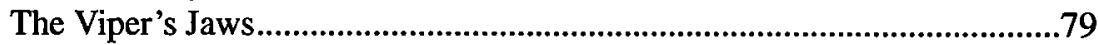

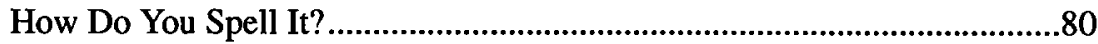

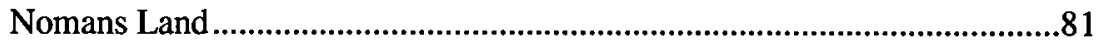

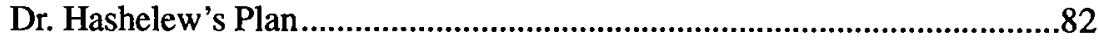

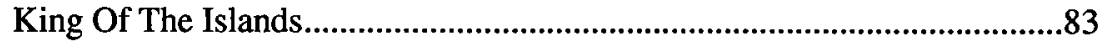

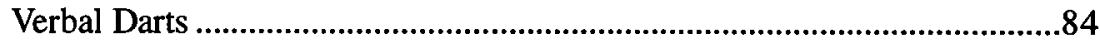

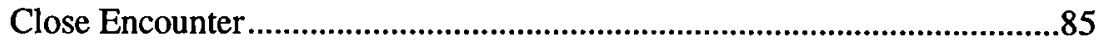

"Starbuck" Offers Prize: A Computer Challenge ....................................................86

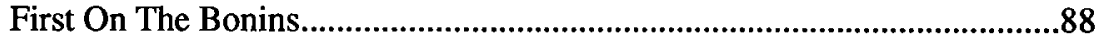

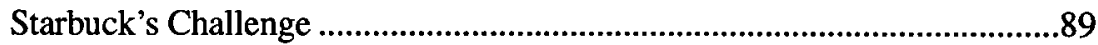

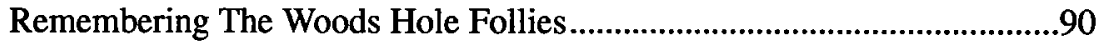

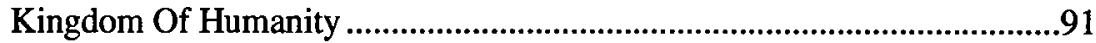

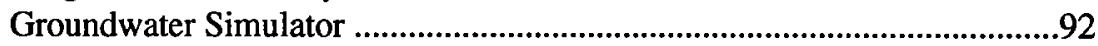

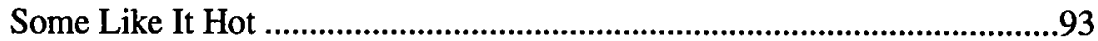

The Comet Is Coming ...................................................................94

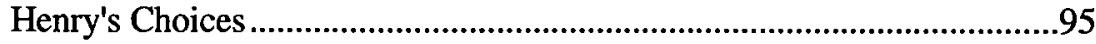




\section{Henry Stommel}

Tank Stommel was born September 27, 1920, in Wilmington, 1 Delaware. His early interest in science, particularly chemistry and astronomy, was encouraged by his maternal grandfather. From his own stories, it was clear that he was of independent mind early on. While still in high school, he "developed a taste for simple ideas interacting with a sparse number of facts."

Hank graduated from high school in 1938 and attended Yale University, starting in chemistry and then switching to physics. He graduated in 1942, a conscientious objector with three years of war work to do out of uniform. He stayed at Yale to teach Navy V-12 students analytic geometry and celestial navigation. During this time he briefly tried out the ministry, but after one semester he found it too constricting - it was mostly about ideas, not practice. His clear sense of moral ambiguity and personal intregrity was well established. Then Hank met astrophysicist Lyman Spitzer and considered further work in astrophysics. Spitzer told him about the Woods Hole Oceanographic Institution and suggested that it might be a good place for him.

Hank joined the Institution staff in 1944, initially developing instrumentation for use with the U.S. Navy submarine fleet and instructing officers in its use, and later doing acoustics work with Maurice Ewing. Neither of these projects really engaged Hank's mind. He finally met Jeffries Wyman (see "On Honorifics"), who was working on cumulus convection. Hank found this work interesting, and it led to his first scientific paper in 1946. From then on, Hank was fully engaged in scientific research. He was a professor at Harvard University for three years, a Massachusetts Institute of Technology professor for 15 years, and then returned to Woods Hole, which was always his spiritual home.

Hank Stommel was the most prodigious oceanographer who has lived, and much has been written about his influence and the breadth and depth of his contributions. His publications include some 140 scientific papers, 12 books and 65 other articles and papers. His list of honors includes membership in the national science academies of the United States, the United Kingdom, France and the U.S.S.R., and medals, awards or prizes from the American Meteorological Society, the Woods Hole Oceanographic Institution, the American Geophysical Union, the American Association for the Advancement of Science, the National Academy of Sciences, the Bedford Institute of Oceanography, the principality of Monaco and the German Meteorological Society. In 1982, he received the Crafoord Prize of the Royal Swedish Academy of Sciences, and in 1989 the National Medal 


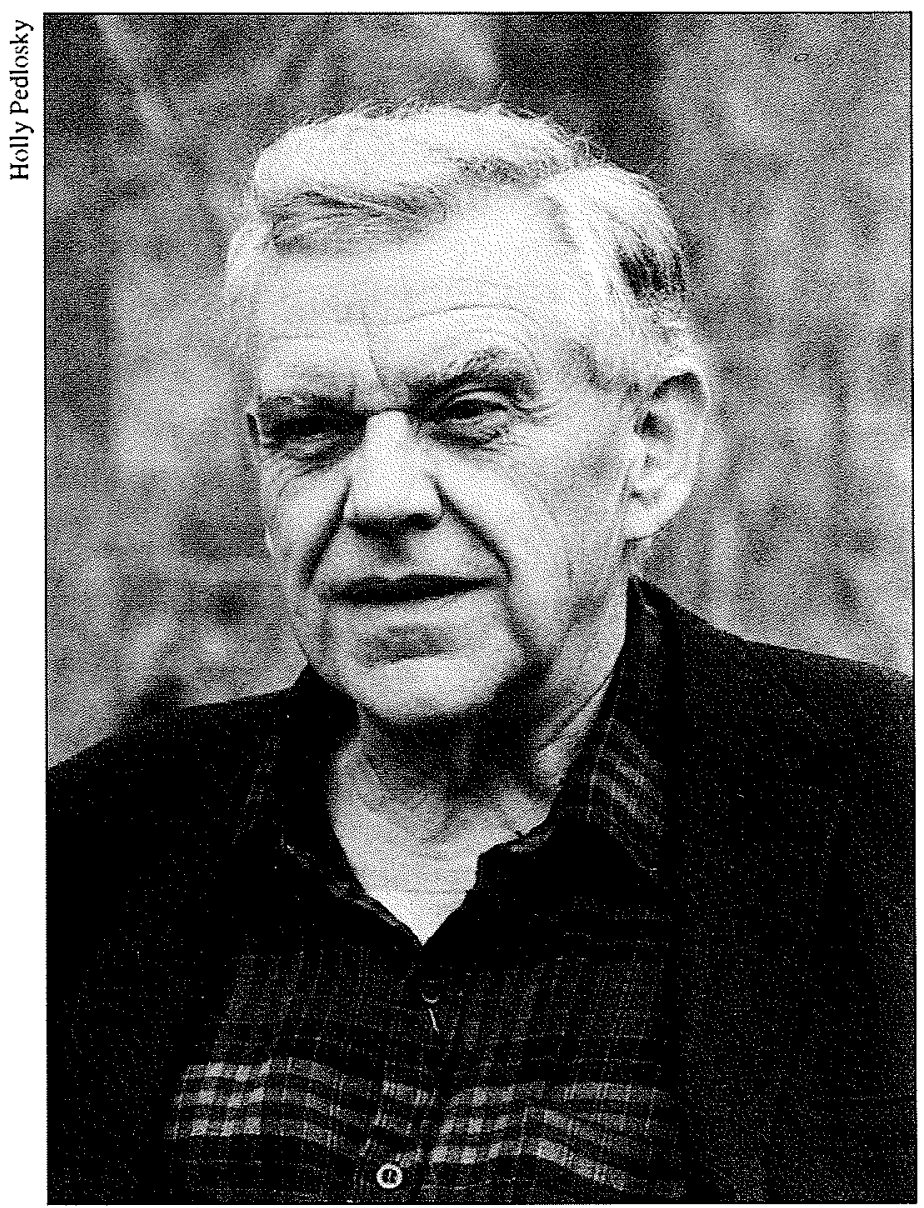

Henry Stommel 
of Science of the United States. What was equally remarkable about Hank was the breadth and intensity of his interest in human beings. His agile mind and voracious appetite for life fueled his amazingly catholic interests.

Hank used the discipline of writing to organize and anneal his thoughts. He was driven to express himself. His sense of humor was also key to the way he interacted with people-he found it was easier to capture people's attention with humor than with a frontal attack. The issues he addresses in these letters and essays range from the sublime to the ridiculous--but often turn on his sense of personal integrity and responsibility and the restraints society imposes on it. Hank refers to his "commentarial ambition," which, I think, underlies much of his nonscientific writing. This was already evident in an editorial he wrote in his high school newspaper exhorting his fellow students to work hard and not waste the opportunity of an education. While he was teaching the Navy students at Yale, he wrote his first book, Science of the Seven Seas. He later felt embarrassed by its superficiality, and though much of it is superficial, the book nevertheless contains the seeds for much of Hank's later interests-lost islands (his Lost Islands, The Story of Islands That Have Vanished from Nautical Charts was published in 1984 by the University of British Columbia Press), as well as many of the fundamental puzzles in oceanography he later addressed.

I don't know where the pseudonym "Starbuck" came from, but I believe Hank found it convenient for several reasons. He refers to one of these in "Dr. Hashelew's Plan" (page 82). He felt the pseudonym gave him freer reign to lampoon the official bodies of the town, the state, etc. A deeper reason though was that it deflected attention from him personally to the content of the writing - it wasn't Hank Stommel, world famous scientist, writing, but rather someone whom you might know personally.

James Luyten Physical Oceanography Department Woods Hole Oceanographic Institution

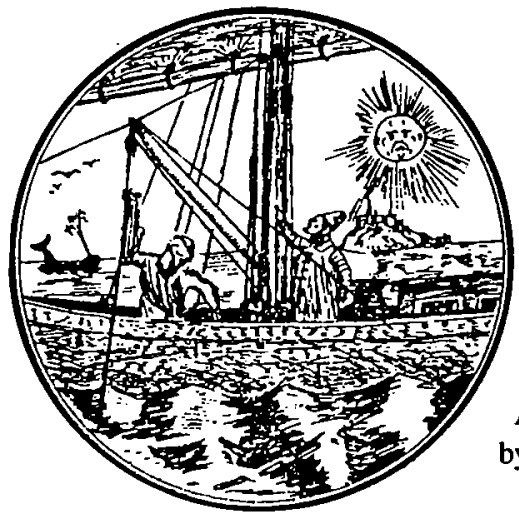

A colophon often used by Henry Stommel 


\section{"Foolish" Traffic Light Starts Mr. Stommel's Friend To Ponder}

\section{Editor of The Enterprise:}

My friend Starbuck, a student of the quantitative aspect of things, and an observer of the American scene, recently wrote me the following letter, which may interest some of your readers:

Poised, as we are told we are, on the verge of a new age of Automation, I marvel at the toleration which we as a people exhibit toward the inefficiency of poorly designed machinery. Let me offer a humble example: the automatic traffic light at Quissett Corners. Normally this signal shows a green light on the main road. When cars approach the intersection from Oyster Pond Road they trip a switch in the road which stops traffic on the main road, and lets them through. The trouble with the system is that cars turning off the main road also trip the mechanism because the road is so narrow, and also stop traffic on the main road for no good reason. This has been going on for years. The machine is an imbecile: $a$ patrolman who behaved the same would be committed. However, everyone submits meekly, tolerantly to this ridiculous machine. Certainly it is within reach of modern technology to invent a switching device which can discriminate between cars approaching and leaving the intersection.

Perhaps you will think this a small matter indeed. But is it? Let us consider that each of us in the United States is stopped on the average twice a week for one minute each time by a similar traffic light. That makes two hours a year for each of the 150,000,000 of us, a conservative estimate. Evaluating our time at $\$ 1.50$ per hour, that represents a total waste of almost one half billion dollars each year-all on the account of poorly designed traffic signals. Were we now to try to compute the loss due to other incompetent machinery: overpowered cars, inefficient heating systems, the telephone dial system, etc., we would be appalled, but would not protest. I submit this paradox to the attention of deeper philosophers of life than I. It is said that matters of national political and economic policy are decided these days with the help of vast computing machines: General MacArthur was recalled from his command on advice of the UNIVAC. The next war may even be declared by machine...the public will remain supine. As for me, I am getting rather scared of machines and very angry at them too-especially that foolish Quissett traffic light.

Starbuck

Henry Stommel Sippewissett 
On February 7, 1958, the editorial below was printed in The Enterprise. It inspired Starbuck, whose reply appears opposite.

\section{Wanted-A New Poet For Shivericks Pond}

This would be called a lake where ponds

Like precious pearls are rare.

A necklace passing beautiful

An heirloom from the skies;

Time fails to touch it with decay,

Its beauty never dies.

This is Shivericks Pond as Mrs. Frances E. Swift, the Falmouth poet, saw it. She wrote in 1894 in her Rhymes of Falmouth:

How oft I longed to dip

My fevered brow in this cool pond

And of its waters sip.

If there are those so tempted today, let them be warned. Those who dip or sip of this precious pearl may not live to write about it. Alas, Mrs. Swift, though the beauty of Shivericks Pond may never die, Time has not failed to touch it with decay.

Shivericks pond still ripples blue as citizens glimpse it from Main Street on a summer day. Benches on its embankment invite visitors to enjoy the watery vista. Around it rise modest homes of citizens, store blocks, our million-dollar high school, the post office of the United States of America.

There may be some in town who know this pond in our village center was named for Samuel Shiverick who was town minister in 1701. Many more know the pond was rechristened some years ago by our Chairman of Selectmen. He called it Falmouth's "public cesspool."

Whew! The literature of Shivericks Pond has changed. Today it is being written by sanitary engineers and bacteriologists, not by poets. We prefer the poets. The state Department of Public Health is more up-to-date. Here is what the department said when it closed Shivericks to ice-taking in 1932:

"Recent analyses show increasing pollution of Shivericks pond, especially so far as the total number of bacterium including those characteristic of sewage."

Years later in 1946, the director of Division of Sanitary Engineering wrote:

"Samples of Shivericks Pond in the general vicinity of the post office showed that the water contained $1,000,000$ bacteria characteristic of sewage per 100 cubic centimeters of water examined which indicates that the water in the pond at that time contained nearly one percent of domestic sewage."

Last October the deputy state Commissioner of Health wrote the most recent apostrophe to our lake:

"Shivericks Pond continues to be polluted with sewage."

Alas that Frances Swift is gone, and after her our Katharine Lee Bates. These bacteriologists are prosy fellows.

Falmouth needs a poet like Oliver Wendell Holmes to save our pond for us as he saved Old Ironsides for the nation.

Have we no modern Julia Ward Howe to write for this month's town meeting, The Battle Hymn of Shivericks Pond? 


\section{Falmouth Is A Friendly Place}

Editor of The Enterprise:

Last weekend, while on a business trip to Avernus, I happened to meet, on the night-boat crossing the River Styx, a microscopic Falmouth resident who was much concerned over the attention which The Enterprise has focussed upon Shivericks Pond. He seemed most apprehensive of some action on the part of the Town which might prejudice his interests in Falmouth, and asked me to forward to you this piece of verse, which, he said, expressed his sincere appreciation of the provisions which the Town has in the past made for him and his business.

Yours faithfully,

Starbuck

I am a jolly Spirochaete

Who lives in Shivericks Pond, And finds there all the dainty things

Of which he is so fond.

My relatives are also here,

The Coli and Bacillus, And comfortably proliferate

With nothing bad to kill us.

We are a friendly, social set;

And soon as we are able, We'd like to visit at your house, And share the dinner table.

The Old World charm of Old Cape Cod

-despite some recent changesReminds us of our former homes:

In India and the Ganges;
And fragrant medieval towns

Return in memories dear

As we inhale the scented air

Of our new home right here.

In other towns a germ like me

Finds things much less secure;

His very life is threatened by

A nasty, costly sewer.

But Falmouth is a friendly place

To keep so nice a pool,

Right in the middle of the Town;

Convenient to the School. 


\section{Canal Electric's Plume Of Smoke}

W

Tednesday, a week ago, Junius and I drove to Boston. The wind was from the south, and when we turned at the Bourne traffic circle to follow the road along the south bank of the canal, we saw ahead of us, on the horizon, a great plume of dark red-brown smoke. Upon reaching the Sagamore Bridge, we could see that it issued from the chimney of the new Sagamore electric factory. As we drove northward along Route 3, the sky was filled with dark billows for a distance of at least nine miles. This ugly pall seemed to overhang the whole of the Miles Standish Forest. By comparison the little cloud from the town dump near Plymouth seemed innocent and harmless.

Late that night, bringing our Russian visitor down from the airport, and extolling the charms of the Cape, we were startled when Dr. Schmoksky exclaimed: "I am surprised by how close we are to the Gulf Stream-the cumulus clouds ahead suggest that it must approach the shore of the Cape quite closely." Sure enough - up ahead, towering above the bridges, the bright moonlight was transfiguring the same electric factory effluvium into a line of immense silvery white clouds, marching across the sky.

"I don't know what others may think" said Junius,"but in my mind a Massachusetts Air Purity agency that acquiesces to such gross disfigurement of the sky by an electric factory, and at the same time bedevils the householder over his homely bonfire of autumn leaves is a monster of bureaucratic obtuseness. Were I an earnest student, bent upon exposing an irrational establishment, I think that instead of demonstrating for a reduction of the drinking age to 16 years, I would solemnly commit the heinous crime of burning a modest pile of leaves in front of the electric factory's door."

"Junius," I replied, "such irrationality does not become you, there must be a reason for so much smoke - a good sound economic reason."

"Undoubtedly," he said in a long-suffering tone, "the darker they can make the sky, the more people have to turn on their lights-even in the daytime."

And so we drove home, sadly, through the hauntingly beautiful nighthaunted by visions of other industrial parks in the Ruhr Valley, and Hoboken, New Jersey, and near Magnitogorsk, and of factories sprouting up everywhere on the Cape. We think that our views are in tune with the times. We display a bumper sticker that says BAN CREMATORIA!...And we think we know the answer to the poet's haunting question: "Where are the leaves of yesteryear?"-in a huge festering pile at the town dump. 


\section{Don't Write Decade Off- \\ It Has Another Year To Go}

$\mathrm{I}$

$\mathrm{t}$ was over a glass of malmsey that $\mathrm{I}$ happened to mention to my friend Junius that the Decade of the Seventies was about to expire. I had heard someone on the radio say it, and usually half my chatter is a reply of what I hear and read. Junius looked pained. "Of course you won't be writing sevens on your checks and letters, but surely you know that the Eighth Decade of the Twentieth Century is made up of the years 1971-1980 inclusive, and ends following Dec. 31, 1980. The Tenth Decade ends simultaneously with the century itself, following Dec. 31, 2000."

Of course, I had to admit that I felt a little helpless, so far as the calendar is concerned, and that I really never even felt comfortable referring to the 1900's as the twentieth century anyway (except of course for the year 1900 itself which really is in the nineteenth century), and that this naturally increased my respect for experts in calendrical matters like Julius Caesar and Pope Gregory. Just to be sure, however, I rather furtively looked at the microfilm New York Times in the Falmouth library, for January 1, 1901and there, just as Junius would have assured me, was a two-column account of the Celebrations for the Turn of the Century at City Hall, complete with fireworks.

As Junius subsequently told me: "It is a little humiliating, at your age, to recognize that you still don't quite know how to count. The calendar seems to bring this out in people. At the turn of the last century the issue was a hot one, and at least one head of state insisted that the century ended on Dec. 31, 1899; but then Kaiser Wilhelm II was a loser. I don't see why it seems so difficult to understand. It illustrates the simplicity of the decimal system, after all, and isn't that why we are all rushing toward metrification?"

It doesn't profit me to argue with Junius. When I began to wonder whether the calendar could really be regarded as Decimal, when there never was a year Zero (for, I believe, Divine reasons), I decided to let the matter pass, and to meekly accept whatever I was told. 
On January 1, 1980, The Enterprise offered the following:

\section{An Answer For Starbuck}

For those who have been fretting over Starbuck's disquisition in the Friday Enterprise about the decade having one more year to go, the question has also roused dispute elsewhere.

This is the way it was explained in The New York Times on Sunday:

Any 10 years make a decade. The 10 years beginning with 1970 conveniently make a decade called the 1970's. It ends tomorrow. However (because Jesus was born in the Year 1, there being no Year 0), the 198th decade of the Christian calendar ends Dec. 31,1980 . So it's 20 years to the twenty-first century. Or 21. 


\section{Twenty Years To Go}

(Our correspondent, Starbuck, who created a rather one-sided controversy a year ago with his insistence that the decade would not end until Dec. 31, 1980, continues to be interested in the subject. A short time ago we received a brief note from him. "Dec. 31, 1980, will bring us to within 20 years of the end of the twentieth century: Dec. 31,2000 . Two more decades to go." This was followed by the following longer dissertation.)

$\mathrm{T}$ he coming New Year will mark that point in time when there still remain but twenty more years in our monstrously cruel, yet peculiarly idealistic Twentieth Century. The new century begins on Jan. 1, 2001 (not 2000 , as implied in these columns during the New Year's euphoria last year).

The New York Times of Jan. 1, 1901, marked the birth of the new century with four columns describing the previous night's celebrations. The official ceremony was in front of City Hall. It began at 10:45 with an overture by Sousa's Band and an address by the President of the City Council in which he expressed the wish "that the crowning glory of the coming century shall be the lifting up of the burdens of the poor, the annihilation of all misery and wrong, and that the peace and goodwill which the angels proclaimed shall rest on contending nations as the snowflakes upon the land," sentiments which, in those innocent days before the advent of the loudspeaker, did not reach the ears of most of the tumultuous crowd. The song which followed, by 500 picked voices of the United German Singing Societies, was more easily heard. The crowd joined in singing "America" and "Ring Out Wild Bells," and cheered and tooted horns.

At midnight church bells tolled twenty times, prayers and addresses were offered, despite the noise in the streets. At City Hall, just as the big hands of the clock approached the midnight hour, all the lights were turned off, and then the entire front of the building burst into light- -2000 electric light bulbs in all-red, white and blue-and an immense electric sign lettered "WELCOME 20TH CENTURY." Simultaneously forty lyddite bombs were discharged in the park and a "gorgeous" pyrotechnic display of exploding bombshells, colored balls, glittering arrowheads and sprays of gold, silver spikes, electric fountains welcomed 1901. The display was

Continued overleaf 
not limited to the official one-from the skyscrapers Roman candles and falling bombs cascaded for more than an hour.

Labor greeted the new century with a dinner and series of speeches in Arlington Hall on Eighth St. Bishops, politicians and leaders of thought were there. There was even a literary man, Edwin Markham, author of "The Man with the Hoe," who delivered an original poem, "The Century Poem." The dinner served cost 50 cents a plate, there was an orchestra, and the surroundings were said to be much the same as those at the more elaborate feasts of people of wealth. Bishop Potter voiced his support for the strike of the Hebrew bakers against their sixteen-hour day; workers were exhorted to make use of night school, and a Mrs. Fred Nathan protested that the list of speakers was made up of fifteen representatives of the unfair sex, and not a single member of the fair sex.

Eighty years gone by, twenty more to come-so much changes, so much stays the same. 


\section{The Wanton Jangling Of A Disneyland Bell}

Tn 1803 Prince Gifford Jr. built the old yellow homestead on what is now 1 Old Palmer Avenue for his wife Chloe (Hoxie) and two little daughters Charity and Mercy. About 1815 "beautiful" Charity married a sea captain, Samuel Moore, but died in childbirth. Captain Moore went back to sea, leaving his tiny son in the care of his grandparents and his spinster sisterin-law Mercy.

Aunt "Massie," as she was called, lived in the downstairs parlor. In her old age (she lived until 1887) she used to wash the family silver each night and secrete it in her room. She was troubled by ghostly noises. Even now, on a cold winter night, with a westerly gale blowing past the eaves, you can hear them.

One wonders what she makes of the bell on the fake "Plymouth Rock Trolley Co." bus that passes the house twice each hour this summer. I think that it disturbs her peace.

Times have changed. Tourists must be transported. But do they need to be entertained by the wanton jangling of a Disneyland bell? 


\section{“Giant's Ashtray" Was Part Of A Water System}

Weeling somewhat depressed by that article in last month's Sunday Cape, I happened to encounter a New York couple looking for a hilltop building lot here in Sippewissett. They were enthralled to find a large parabolic stone dish at the summit and had consulted our local archeologist, Dr. Hashelew, who pronounced it to be a prehistoric space telescope left by early visitors from off-Cape. Local children know it as the Giant's Ashtray. But it is really a monument to an old man's folly, the handiwork of Samuel Moore (1844-1935), Sippewissett-born inventor and entrepreneur.

It was Uncle Sam, who as a boy, planted the huge old maples on our corner, who during the Civil War learned the mechanical arts first-hand in the locomotive shops of Taunton, who invented a machine for manufacturing those little chains of brass balls to be found in every pull-chain lighting fixture today, and founded a prosperous metal findings concern in Providence.

At the age of 65 he decided to convert his grandfather's barn into the house now owned by Douglas and Shirley Webb. In those days there were no water meters-rates were set by the nature of the plumbing facilities. Uncle Sam was so enraged to discover that his rates would be doubled because of a projected upstairs toilet that he decided to build his own water system, both for the house and for irrigation of his apple orchard.

A well was dug at the bottom of a pothole near the railroad tracks, and a Stirling hot-air engine installed. A windmill was built on the hill and the great dish as a reservoir. In laying out his water system Uncle Sam was a very confident engineer. He depended upon his eye instead of on a level. Upon completion of his private waterworks he discovered that there was insufficient pressure to fill the upstairs toilet tank.

Following his death in 1935 the elaborate system fell into disrepair. A hurricane toppled the windmill. One dark night the Stirling engine was spirited down the railroad tracks towards Woods Hole. All that is left is a cracked parabolic dish in a tangle of poison ivy.

If you are looking for evidence of visitors from off-Cape, you won't find it in the Giant's Ashtray, but in the numerous fresh-dug cellar holes along any back road in town. 


\section{Early Tourists}

T abor Day is past. The tide of visitors ebbs. Cape Codders look forward to the halcyon months of fall. Our thoughts revert to the veteran tourist clergyman-president of Yale, Timothy Dwight. For many years he traveled through New England during the September recess, when the students were released for harvest work at home.

In 1800 he rode through Barnstable to Provincetown by the north road. The closest he got to Falmouth was a visit to the praying Indians at "Marshpee." Generally impressed by the industry and piety of Cape Cod farmers and fishermen, Dwight thought less of some of the innkeepers whose hospitality he was forced to endure. At Well's Tavern in Truro the proprietor, "a detestable Frenchman, presented an enormous bill, nearly double to what we had customarily been charged before" and swore and cursed when Dwight protested.

At Atwood's in Wellfleet he suffered "a grumbling old Democrat, who together with about half a dozen of his uncouth, unmannerly and impertinent neighbors regaled us with more profaneness and questions about ourselves and our business than I imagined could be found in any one house in New England."

But he was grateful to the old fellow's wife for "Good Beds."

He found the high moral tone of Provincetown most pleasing, and their 140 houses, 140 cows, ten yoke of oxen and two horses. He found much of the Cape bare, bleak and desolate, "the inhabitants having invariably cut down their forests." He commented upon the sparse water supply and the precautions that farmers took to protect their orchards against the winds.

He noted the state law that required the inhabitants to plant beach grass to impede the sea, which threatened to sever Provincetown from Truro.

Writing of what he regarded as the inferior quality of the houses beyond Barnstable he may have coined the phrase of what "may be called with propriety Cape Cod houses." He determined that the chief vice was intemperance, particularly in the western districts. And he predicted that the future industry of the Cape would be salt-works.

Dwight may have been the first tourist. In his own words, he and his party "were the first who had ever traveled over that peninsula from motives of curiosity." He could not foresee how many of his descendants would follow his trail, how we would so foul our urban nests that we seek refuge here on our "disagreeable sand hills" at the margin of the sea. 


\section{Recalling Henry Parker}

W

hen our boys were small there was nothing like the night before the opening of the trout season and almost no sleep. Excited whispers, restless movements of an overnight friend unaccustomed to a sleeping bag on the floor and flickering flashlights to inspect the slowly moving hands of the alarm clock kept everyone awake.

Then, about 3 A.M. the sounds of furtive footsteps, three pairs of pants being donned, the clunk of rubber boots and of doors opening and closing, and they were off on the great adventure of the hike to Goodwill Park through the mysterious heavy darkness, the dripping boughs and the slippery descent down cold damp banks to the pond. There reigned the strict discipline of self-imposed silence, stern commands to "douse the glim" in boyish tones, or perhaps the stifled cry of some small unfortunate whose hip boots unexpectedly filled up with cold lake water.

With the first light of dawn the dim outlines of the trees and pond-side boulders began to show faintly, and one could discern an earnest tiny fisherman perched on each one, for all the world like sleepy little springtime toads. These were treasured hours free of parents and teachers, on their own in the great outdoors. Some brought home their catch with pride, a pickerel or two, to bestow upon a hesitating mother.

The counselor, friend and hero of these little boys was Henry Parker. From his counter in the rear of Eastman's he outfitted them all: a five-cent hook here, a two-bit lure there. And more than this, too, for he introduced them to the magic world of field and stream. With the utmost patience he helped them wind their reels with line, and more than once he took them out back to Shivericks Pond to demonstrate how to cast a lure. On one such demonstration he even caught a fish on the first cast.

When the snow thaws and spring comes to this town, the peepers raise their voices from our ponds, and the light is still dim in the sky, there must be many men now nearing middle age who for a few moments recall Henry's kindness in their hearts, and the first clear feeling stir within in them that, though boys, they now were men. These living memories of the gift he gave are a kind of immortality that few of us have earned. 


\section{On Behalf Of Those Unexpected Discoveries}

Following the French Revolution the royal tombs in the cathedral of St. Denis were demolished, not by the mob, but by contractors under orders of the government. On Aug. 6, 1793, workmen armed with hammers and crowbars began to conduct a posthumous massacre of the kings and queens of France, beginning in chronological order with Dagobert. There is nothing like a professional to do a thorough job.

Today, with the revolution of computers and photocopying there is a similar ferment amongst librarians. Some of the best books obtainable from used book dealers are library discards. Through such dealers I rescued a rare little pamphlet on missionary ships in the Pacific (discarded by the Beaumont, California, library), an old book on shipbuilding in New York City (the Kingston, Rhode Island, library) and a wonderful old biographical dictionary (from Orleans).

The argument seems to be that seldom-called-for items clutter shelves, and if ever needed, can be obtained on loan or copied from a larger library. But what about that reader who only learns about their existence by unexpectedly finding them on the shelves?

A form of this discarding mania has penetrated professional libraries and, in a mild form, touched our great research library at Woods Hole. As a result of a six-month "user survey" it has been found that certain scientific journals are seldom referred to. During the past six months some were not even looked at all. So the inexorable machinery has been set in motion to cancel subscriptions, some for journals whose holdings extend back many years. The excuse is economy, but when one considers the lavish funds expended on building renovations last year and the very expensive new elevator that has replaced the old but serviceable one that was there before, one wonders.

Among the journals scheduled for the guillotine is the venerable Annales des Physique - though the library holds all previous issues back to 1789. Even those half-mad zealots of the Goddess of Reason who ordered the demolition of the royal abbey of St. Denis, to the dishonor of the French nation, spared the Annales des Physique. 


\section{Leaves Of Autumn...} rost comes, and leaves begin to fall. Autumn bonfires no longer scent
the air. They are banned by law. One of those "back to earth" mailorder catalogs now offers table-top braziers for city dwellers who want to recapture the memory of what they call "mother nature's incense" in the privacy of their apartments. You can order plastic bags of pine cones and hand-rolled oak leaves at $\$ 7$ a pound.

Struggling with nostalgia and pyrophilia, I decided to look up our own Dr. Hashelew to see what progress he had made on his mechanical leafeating machine. His old Stanley Steamer was out on the driveway. He was rather blackened, smeared with oil and had a dirty bandage across his knuckles. Something like a giant vacuum cleaner and leaf shredder had just been hooked onto the front bumper. I was just in time for a field trial and demonstration.

Once the leaves are sucked up and pulverized they are fed into the firebox under forced draft. The steam generated drives the car and the assorted blowers. Exhaust steam quenches the ashes and converts them to a grey paste that fertilizes the lawn. It is indeed an ecological triumph; it doesn't use a drop of gasoline, and with a good head of steam it can give the doctor a free ride to the grocery store.

At present Dr. Hashelew is perfecting a way of preventing the ash from clogging the boiler tubes. In a Stanley they are as thin as a pencil. His ingenious solution to this technical problem is still a secret-patent pending.

We had a grand demonstration, running the stately Steamer up and down under the doctor's maples. The rear-end crank shaft dripped hot grease. The heavy wheels left ruts in the grass. The neighborhood children shrieked with joy at the "Goody Car." We all thrilled at the clouds of white steam, the whirring gears and pounding pistons and exclaimed at what marvels the great machine could do. All except Aunt Harriet who was heard to murmur, "Not much 'provement 'pon a rake and match." 


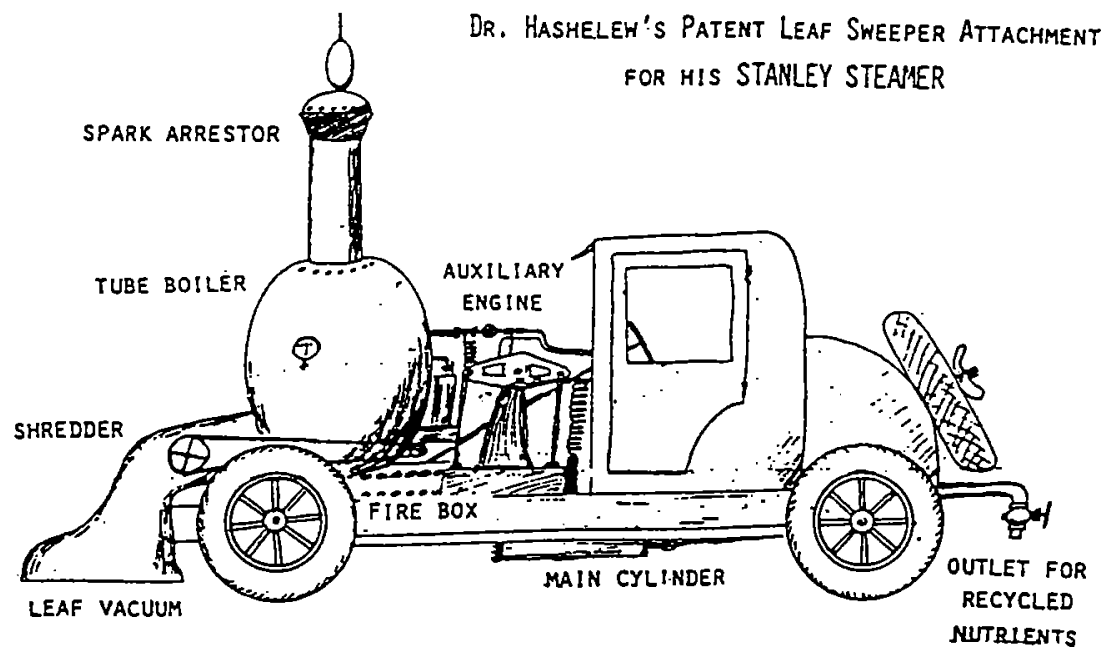




\section{Miraculous Multiplication And Simple Division}

$\mathrm{s}$ the town wrestles with the prospect of a population explosion, one
thinks back to the days of the Han Emperors, when there were only 12 million households in the whole of China.

A monk named Wun Tu, while deep in meditation beside the $\mathrm{Yu}$ Kiang, the most sacred river of Kwangsi, descried a glittering object beneath the surface. Hitching up his gown, he waded into the chilly stream and picked it up. It was an ancient piece of bronze, worn thin and polished by the running water. Gazing into the shining surface he saw a second self. His abbot was impressed by the Sublime Reflection-which could so effortlessly multiply the treasures of the temple.

News of Wun Tu's discovery sped across the countryside. Local farmers saw their crops increase and the doubling of their rice fields and the number of their sons. Now that they needed only half their previous harvests they rushed to the Planning Board to subdivide their farms in anticipation of the hordes of new settlers about to appear on the land.

In time the fame of Wun Tu reached the Imperial City, the High Generals dreamed of multiplying their troops, and the Royal Mathematician, while sitting in the barber shop, deduced that two such reflecting bronzes could affect infinite remultiplications.

Wun Tu was summoned to the Celestial Presence, before whom he made a low and reverent kowtow. "Is it true, Wun Tu, that you have found the secret of Sublime Reflection, that anyone who gazes into the bronze can make one into two, and have you brought it with you to Our Throne?"

Wun Tu groped in the pockets of his robes for the polished bronze. It was awkward to do because he was lying face down on the floor. The Emperor put out his hand, then hesitated as he suddenly perceived that if he looked into the mirror there would be two Emperors. There was a brief moment of stillness. In a sad voice the Emperor proclaimed: "Magician of Miraculous Multiplication, I now reward you with Divine Division!" and with a stroke of his sword cleaved Wun Tu in half.

The moral of this story is not that the many are the enemy of the few, but that unexpected perils await those fools who trust the promise of the bronze mirror. Don't you be Wun Tu. 


\section{A Way To Die...}

$\mathrm{W}^{\mathrm{e}}$

e buried Francis Claude Ronne on Wednesday. Born in 1910, Claude came to work at the Oceanographic in June, 1944. At first he worked in the darkroom establishing a standard of excellence. Later he was able to leave it in the charge of his apt pupil Charles Spooner, upon whom he also bestowed an interest in old clocks.

The meteorologist Joanne Simpson played a large role in Claude's life. She encouraged him to do science, beginning with some work on air flow over Nantucket in 1950 and, by 1953, an expedition to the Caribbean.

In those days the Oceanographic had a series of aircraft. With Joanne and Andrew Bunker, they carried Claude to the Pacific, the Mediterranean and the Indian Ocean. His specialty was time-lapse photography of tropical clouds. For many years Claude also recorded, from the air, the changes in the northeastern U.S. coastline- $\mathrm{a}$ invaluable documentation by photography of the changing shoreline.

A lifelong bachelor, Claude's courtly ways exerted powerful charm. Many a Woods Hole girl cast wistful eyes in his direction, and friendships developed, up to a point. Without question Claude was loveable-toward the end one could see it in the sweet concern of the nurses devoted to his care.

Upon his retirement, after 30 years of service, he found it necessary to supplement his $\$ 4,800$ pension by selling his house in Falmouth, and he moved back with his sister in Orleans.

He cherished the old hymns and the old liturgy of the Church of England - though during most of his life he remained outside of it. Like all of us he sought an insight into the meaning of his life-we pray that he has found it. He bore the anguish of the last year, when during the long dark hours of the night the fear of death pressed upon him, with fortitude and resolution. We cannot know what fate is being woven for us upon the humming loom of time. Will we respond with surprise and rage? Or will we, as Claude did, receive it with resignation and philosophical calm? 


\section{Perhaps A Fresh Start}

This is the time of year that we used to see deer in our apple orchard. 1 Early one morning, in hunting season about thirty years ago, my wife saw a man with a rifle a short distance down the road from our house. Hurrying down to him, she said, "You can't shoot that thing so near to our house and our children. If you don't leave, I'll call the police." To which he replied, "You won't have far to go, I'm Chief Baker."

I sometimes wonder how the wild things manage to make it through the winter: the mice, the voles, the skunks and raccoons. There is all that cold and wetness, the hunting season and the new house lots proliferating in all their once-secret haunts. We, on the other hand, have our snug heated home and the harvest from the supermarket.

On top of it all, we are now playing with the power to destroy the world. Our leaders joke of megadeaths and have the missiles poised to prove it. If some magic were to transport you into an elegantly furnished oval-shaped room, with an elderly gentleman seated at a desk with a red button on it, you might expostulate, "Get away from that thing, or I'll phone the President!" Then he might reply, "No need to call; I am the President."

A nuclear winter might be more than the wild creatures could endure: all life might disappear.

If I were one of those Greenpeace people, I think I might agitate for a return to biological weapons, designed to be specific for human beings. Then, if we bring on the apocalypse, the rest of nature could survive and evolution begin again. Thousands of years later, when we come down from the trees once more, we might just be more humane. 


\section{An Old Gentleman}

O omehow we all knew when the last steam locomotive was going to leave Woods Hole. I walked down to that high corner next to the Woods Hole Library where the branch of the Falmouth National Bank now stands. In those days it was a grocery store that carried the now forgotten Oak Hill brand of canned goods. I found Edward Swift standing there. As the weary old engine labored up the line past Little Harbor, Mr. Swift murmured, "I thought I'd see the last one go, 'cause I saw the first one come." As a boy he had built Cape Cod windmills with his father, and he lived to be more than a hundred years of age.

On another occasion, needing some deck paint for my catboat, I went to his hardware store in a little barn behind his house on School Street, bordering Eel Pond. I told him that I wanted it light green. He brought out an ancient can of very dark green paint with a sly grin asked "Ain't too light, is it?" Of course I took it.

During his last years the sheltered peace of his backyard store was shattered. The adjoining Shiverick house and lot were offered for sale. ExSenator Walter Luscombe, who had a nose for a profitable deal, advised one of his younger acquaintances to purchase it on speculation. The house itself was moved. The great old shade trees were all cut down. The whole corner was made into a parking lot, paved with blacktop right up to Mr. Swift's back door. For several years, until the land was purchased by the Oceanographic for Redfield Laboratory, he endured the summer turmoil of a noisy commercial parking lot.

Once when I was with him, a harried traveler to the Vineyard, finding the parking lot chock full, parked his car on Mr. Swift's lawn. Upon seeing the old gentleman emerge from his barn, the traveler groped for his wallet. Mr. Swift shook his head and said, "You can leave your car all right, but I've never charged anybody for it before, and I don't intend to start now." 


\section{Getting Out Of Hand}

Thear that Moonskull McDoughnut has opened a new permit agency at 1 the new shopping mall down by the steamboat dock in Woods Hole.

Seems that getting permits is getting to be so complicated that we need an agency to sort things out for us-like income tax accountants and the insurance people. Nowadays you need a permit for everything. The story is going around that a city lady down here went to town hall for a permit to put up a storm window, and they actually gave her one-five bucks. I can't vouch for the truth of that story.

But then there's this fellow that got summonsed for cutting his lawn. Maybe I'm going to need one to shovel the sidewalk this winter because it might inconvenience the snowshoe rabbits. Time was that you could sink an old engine block anywhere in Little Harbor for a mooring, or shoot a cow, burn the stubble in your field or tear down an old shed without a permit. The only permit you needed was to be a U.S. citizen.

Over there in Japan they make certain old people turn into national treasures. They can't change the color of their clothes without a permit. Don't bet your boots that the idea won't catch on here. Why, if it does, there'll be a Town Treasure committee. And if they pick you, as being particularly picturesque, you couldn't go to the barber shop for a haircut without a permit. 


\section{Mail Order...}

7 hought you might like to see a copy of this letter from our farmer 1 friend in Hatchville:

Mr. Woody Burns

\section{Sales Manager}

Green Rock Stove Company

Brattle Falls, Vt.

\section{Dear Sir:}

That standard solid door soapstone stove arrived safely the other day about supper time, by Tail-Gate Truckers. The driver had a sore back, and there wasn't anyone else with him, but I managed to get it down all right at the end of our lane. My scales is broke, but I'll take your word for it that it weighs 450 pounds.

I managed to drag it up the hill to the front door of our farmhouse. I lost the use of my right arm when the Ferguson tractor went through the barn floor back in '21, so I had to get my mother to help me get it upstairs. With my pulling, and her shoving we angled it into the second-floor sitting room. Then we got it uncrated, and she just stood there admiring it. She exclaimed "My Stars, that will last my lifetime!"

Well, we are mighty pleased with the way it looks. Oh, I almost forgot-that chromium spring handle that's 'sposed to go on the lid? Well, you didn't send it.

Yours truly, Cornelius Cobb 


\section{The Other Cape}

7 he planet Saturn has just set. It is 2 A.M. Oct. 12. Lookout Rodrigo de

1 Triana suddenly descries land ahead. America has been discovered, an event which we celebrate on the wrong day for the convenience of weekenders. The Bahamas are, of course, very nice, especially as winter approaches, but this is not what Columbus had in mind. Until he died in 1506, after his fourth voyage, Columbus clung to the idea that he had reached the East Indies-although he couldn't account for not finding any pepper, cloves or nutmegs.

Back in Lisbon, the practical Portuguese navigators had already unravelled the puzzle: Batholomeu Diaz de Novaes discovered the Cape (of Storms, or Good Hope, as the King preferred) in early 1488; Vasco da Gama rounded it in 1497 and visited Calicut, India, in 1498.

Within 12 years the sea trade of the Indies and Indian Ocean was completely under the control of the Portuguese nation. This was largely the work of Alphonso Albuquerque, who may well have been the greatest naval strategist and fighting commander of all time. Inspecting charts captured from Arab galleys, Albuquerque saw that it was necessary to dominate the entire 3,000 miles between the Malay Straits and the Persian Gulf. By 1507 he subdued Hormuz; in 1510 he conquered Calicut and Goa, and in 1511 he captured Malacca. He held in his hand what Columbus had groped for.

The 500th anniversary of some of these heroic exploits is coming up soon. I hope somebody is planning for it. Perhaps 1986 is not too soon. I think it was in 1486 that Diaz received his commission to search for and find the Cape-the other one. 


\section{Oh Captain, My Captain}

$A$ s institutions grow, they pass first through a youthful, free-wheeling A stage and then through a more structured phase. It was perhaps the U.S. alarm nver Sputnik in 1957, and the loud snapping of the federal purse strings that woke some of the trustees from a long sleep and triggered such a change at the Woods Hole Oceanographic Institution. The great amateur tradition, personified by Director Columbus Iselin, gave way to a new professionalism, engineered by the president of a nautical equipment firm and encouraged by an MIT management-school consultant whose business acumen had formed the Uranium Corporation of America. An "up-or-out" rank system was imposed, salaries and pensions augmented, Ph.D.'s recruited and a semi-tenure system introduced. The old informal times, with Columbus at the helm, were gone forever.

Two instances illustrating the human quality of our captain come to mind. The first concerns poor old Joe, once a schoolmaster, who proved to be of limited research ability. Now it should be remembered that no one was ever fired in Columbus's time. Puzzling over how to keep him usefully employed, Columbus sighed: "I just can't let Joe go-why if I did, he'd return to school teaching and that would be a crime against American youth."

The second instance concerns Columbus's effort to calm down the furor following a break-in at the carpenter shop. In those days, with a host of amateur woodworkers about, the carpenter had to guard his tools with the temper of a she-bear. Thus Stan had honed an edge as sharp as that of his plane irons.

One weekend the Atlantis departed on one of Doc Ewing's hastily organized cruises. Finding himself without tools, one of Doc's most stalwart disciples took down a fire axe, broke the panel in the shop door and took some of Stan's favorite tools.

When Monday morning rolled around, Stan was in a proper rage. Storming upstairs to Columbus's office, he explained the situation in heated terms, ending with: "Mr. Iselin, what should I do?"

To which Columbus smoothly replied: "Well, Stan, if someone had chopped down my door and I was as mad about it as you are, I'd get an axe and chop his door down." 


\section{Trial By Gutenberg}

Y

ears ago in a time before the flood of junk mail, when I was a bachelor living at the Episcopal Rectory in Woods Hole, I decided to answer all the classified ads in Popular Mechanics magazine. For months afterwards there was a gratifying deluge of sales material offering all sorts of bargains. The most persistent of all was the Paw Paw Chemical Toilet Company-which I finally managed to cut off by returning one of their missives marked "deceased."

I did, however, succumb to the blandishments of the Kelsey Printing Company, Meriden, Connecticut, whose ad titled "Make Money, Do Your Own Printing" was so alluring that I ordered their 6 by 10 Excelsior press, several fonts of 8 point Bodoni, a small font of 24 point Clarendon and enough Old English for a masthead. This truly venerable firm has used the same enticing advertisement since at least 1876; it can be seen in the program of the Philadelphia Exposition in the possession of the Sturgis Library.

At first my job printing activity was confined to calling cards, Christmas cards and the programs for Mary Fassett's Falmouth Friends of Music. The latter was the cause of my press's demise, since it exhausted my supply of upper case "M's" in setting up the list of patrons with their repetitive Mr. and Mrs.

The most ambitious project using the Excelsior was the weekly publication of The Woods Hole Adjudicator. It was motivated by differences of editorial opinion with The Enterprise. The labor of setting up type and then distributing it by hand was very discouraging and led me to curse Mr. Gutenberg's invention of moveable type. The profits at 1 cent a copy were disappointing. After a few issues-none seem to survive-The Adjudicator collapsed, bunkrapt, so to speak.

Nearly forty years have passed-years of repressed commentarial ambition. The rollers on the old Excelsior sag with mold. The tub of printers' ink is hard as a rock. There is a better way. If you can't beat them, join them. 


\section{When The Sun Goes Down}

7 he printer of a school atlas fifty years ago needed a large stock of red 1 ink. The British Empire covered so much of the world that there was always a part of its territory where the sun was within an hour of the local meridian.

Recently there was an alarm that with the cession of Hong Kong to China Britons might be left occasionally in the dark. An editorial in the London Times reassures us that this will not be so, for there are three lonely island outposts, St. Helena, Pitcairn and Diego Garcia sufficiently spaced in longitude and close enough to the equator so that the sun will always be shining upon one of them even during the austral winter. For purposes of perpetual insolation the French Empire is even better situated.

If we can extend the idea of sovereignty to artificial satellites, the U.S. may be considered best off of all. With the help of the now-deported Dr. Rudolf amongst others we have so many of them orbiting the globe that even the coming Navstar navigation system alone will feature five satellites above the horizon everywhere at all times.

The sun truly never sets on the American Empire. Like that of our British cousins it has a large military component, is very expensive to maintain, stimulates our national pride and no doubt can bring much good to the world. The mores of the Pax Britannica, when Britain ruled the waves, were said to have been formed on the playing fields of Eton. Those of the Pax Americana, when America rules outer space, may be formed on the video screens of Atari.

Great Britain dismantled its empire when its people ultimately realized that for one people to try to rule another is degrading to them both. America may abandon its thoughts of further militarizing outer space when it concedes that the effort toward global dominion of one ideology over another could lead to dissolution of them both. And should Armageddon actually occur, and a few outlying satellites still survive, the sun would never set on any but an empty empire. 


\section{A Man Too Gentle For This World}

$\mathrm{O}$ n a February morning in 1962, 76-year-old Frank Whitman walked into the Beebe Woods and disappeared-so we believe. Searchers were unable to find him. Even a helicopter was of no avail.

Frank was a lonely recluse of a man. He lived in a vacant room at the Marine Biological Laboratory, where his father had once been director. Mrs. Montgomery used to see to it that he received a monthly check from Ohio. She could usually tell when his cash was running low because the cookies that the librarians kept for afternoon tea would begin to disappear. He was excessively shy. A nighttime visitor to the library, walking down the dark halls or in the stack during the winter when no one else was around, would sometimes be startled by a flutter of retreating footsteps as Frank scurried away.

Frank used to drive an old automobile, and upon passing another car he would slump down in the seat to avoid being seen or pull a newspaper over his head. His driver's license was taken away. Early most mornings he would trudge up to the woods to view the wild creatures there- his specialty was birds, and he sometimes wrote notes about them for The Enterprise.

It was said that once he escaped from a mental institution and was tracked down with a pack of hounds. He may well have regarded his liberty as precarious. One had to approach Frank with the patience that a small boy needs to get a squirrel to come and feed from his hand. So it was a personal triumph for me when I could sometimes get Frank to accept a ride back to the MBL from somewhere along the back road near Miles Pond. He was very silent on these occasions, muttering only a single sentence like: "I saw a brown thrush this morning." Frank was too gentle for this world.

Eleven years following his disappearance a homeowner walking around his lot on the newly developed Two Ponds Road found a scattered skeleton, chewed upon by animals. If this be Frank's, his pauper's grave in the town cemetery* is peaceful and quiet enough, one of the nicest places in our town. If not, he is still with the other wild things, out under the open sky. Caelo tegitur qui non habet urnam.

* Note: A correcting letter from Oliver B. Brown, published November 9, 1984 , notes that the records he keeps for the Woods Hole Cemetery and the Churchyard of the Church of the Messiah in Woods Hole show that the bones were buried there. 


\section{C.O.Whitman, His Fateful Decisions}

$\mathrm{O}$

$\mathrm{n}$ a quiet Sunday morning, toward the end of Indian summer, a reader in the Marine Biological Laboratory library can hear the cooing of the pigeons huddling under the eaves over the main entrance. I know that they are a terrific nuisance, fouling the steps and clogging up the vanes of the air conditioners.

They are always there, despite sharpshooters, exterminators and the efforts to capture them made by trainers of bird dogs. To me their voices are repeating the refrain "cow, cow," the initials of Charles Otis Whitman (18421910), the first director of the MBL who was so interested in pigeons that he needed two freight cars to transport his collection of them between his winter job at the University of Chicago to Woods Hole and back again.

Born in North Woodstock, Maine, from a stock noted for its eccentricity, the young Charles early took an interest in minerals and birds and converted the house into a museum. He was much more likely to engage in fierce religious discussion with his father than to play with other boys.

He prepared for Bowdoin under his Uncle Leonard, a man famous for his obstinate temperament, worked his way through by teaching on the side and graduated in 1868. His hair, first worn long and black, had turned a pure white. And he had learned to conceal the boiling inside him with a mask of gentleness and courtesy.

It was Edward Morse's course at Penikese that launched him into marine biology and a two-year stint of teaching at the University of Tokyo, where he introduced his students to collecting trips on Kagoshima Bay. Differences of opinion with the University authorities led to an abrupt departure but did not sever a longtime affection for the biologists of Japan.

C.O. Whitman made three decisions as director of MBL that made it the distinguished and unusual place that it is today. One, when a Boston group of the trustees voted to cancel the summer session because of lack of funds, he got those who lived in the midwest to overrule the vote - the result being that it became a truly national institution.

The second was when Mr. Crane offered to take over the trusteeship in exchange for financial stability. Whitman declined and got a building from him instead. This established the unusual precedent that the MBL belongs to the scientists who work there.

The third occasion came when certain trustees hearing that the Carnegie Foundation was planning to start its own marine laboratory, voted to turn themselves over to it for the sake of financial security. Whitman reversed the vote and secured an endowment from the Carnegie people instead and established the independence of the MBL. 


\section{A Curious Choice...}

$7 \mathrm{o}$ the Committee for Dedicating the Treatment Plant:

1 One of the happier aspects of the sewer construction is the way that it forces us to find alternative routes around town. The habits of the past are broken, and we see more of the world around us. Each morning there is another way to go to work.

Hundreds of feet down, percolating through the sand, clay and gravel, there is about a century's accumulation of groundwater. About $1 \%$ is renewed each year by rainfall and about the same amount flows to the sea in our little rivers and out under the beaches through unknown pathways laid down by the glacier that formed Cape Cod following the Ice Age. Only a small fraction of this perennial flow is tapped by our water supply systems.

Our knowledge of these underground conduits is very slight. The great plume of pollution coming southward from Otis is only partially mapped, but samples from wells near Blacksmith Shop Road suggest that it has already reached there. The registered letters mailed by the health department to residents of part of West Falmouth informing them that they. should discontinue use of what wells they may have suggest that another plume is expected to flow down toward the west from the new spray irrigation plant being installed. It seems safe to assume that no one really knows exactly where the new plumes will flow. But there can be little doubt that the heavy-metal pollutants that are introduced into the groundwater will increase in concentration in it as time goes by.

It would seem churlish to raise these doubts at the very time when the town is celebrating the final solution of its sewage problem-and I have no taste for hemlock. But for the sake of future historians-those recorders of the folly of our race-it might be useful to deposit a complete set of documents leading up to our decision in a cornerstone at the opening ceremony of the new disposal plant. The names of those who opposed alternate plans successfully are not important, but their reasons for rejecting what appears to us to have been the much safer ocean outfall in Vineyard Sound might be of interest to our descendants.

To this observer it seems that we have made a curious choice: in our distaste at the prospect of swimming in these effluents in vastly diluted form we have chosen instead to drink them. 


\section{Father Of The Graham Cracker}

T $\mathrm{t}$ was 150 years ago, and the U.S. was in the midst of a great health fad. Skeptics were being convinced that it was good for their health to take a bath now and then, even in the winter, and those who actually did so as often as once a month thought themselves far ahead of the crowd. Of course it did require a fair amount of resolution in the days before the California bathroom.

Sylvester* was born in 1794 of a Connecticut clergyman-physician who was 72 years old at the time, so you can see that he sprang from a vigorous stock. Caught up in the anti-alcohol and anti-tobacco crusades of the time, he early turned his attention to food itself.

He preached from Deuteronomy of the stubborn son who was stoned to death for gluttony and drunkenness. In Nature's Own Book (1835, New York) we read of a poor fellow who was persuaded to give up his greatest earthly comfort, coffee, by the power of Dr. Graham's oratory. "The torrent of truth poured upon me and made me a thorough convert, I heard and I trembled. That Sabbath morning I redeemed myself from the curse of caffein."

Our own concerns with health make one wonder whether Graham was just ahead of his time and whether it won't be long before the surgeon general adds coffee to his list. What a change that will make in offices across the land.

The greatest fame that attaches itself to Dr. Graham's name derives from his fervid advocacy of roughage. His cereals could be found on the breakfast table of Brook Farm. Popular hagiography, if not the medical historians, has elevated him to the immortality of Pasteur (milk) and Lister (mouthwash). His name lives in our time as the father of the graham cracker.

*Sylvester W. Graham 


\section{Ambition}

$\mathrm{T}$ here once were so few winter residents on Sippewissett Road between the icehouse and Will Gifford's farm that the road was sometimes left unplowed.

Dr. Cecil Drinker and his wife Kathryn, also a physician, lived in the middle of three old houses now surrounded by Beccles Road. Cecil was a wonderful and somewhat cantankerous man. With his brother, Phillip, he invented and developed the ironlung that saved so many victims of infantile paralysis before the Salk vaccine.

His discontent was deep, and he wanted desperately to be the dean of the Harvard Medical School. To his chagrin, when the long-awaited chance came up, the School of Public Health was made separate, and he was appointed dean of that instead. It was not enough to satisfy his ambition. He made his disappointment known. After a drunken appearance at a general faculty meeting in University Hall, he resigned the next day. In his retirement, he and Kathryn edited an important medical journal.

When we were still a young married couple, my wife and I got to know the Drinkers well. They were splendid company in the empty wilds of Sippewissett. Once when they came to dinner, my wife served roast lamb with a garnish of what she took for mint, gathered in the backyard. Dr. Drinker complimented her on the delicious catnip sauce. There was something boyish and rough about him-Tom Sawyer with a stethoscope.

His last days at Pocasset were not easy. He fought for life and raved. An outspoken atheist, he cried for Jesus. Kathryn, who had sustained him all the years, was suddenly taken to Tobey Hospital and died. In his panic, he told his old friend and physician, Stanley Cobb, that he was going to order a taxi and go home, to which Dr. Cobb replied, "Well, Cecil, we can't keep you here against your will, but there's nothing that prevents me from following you there and picking you up from the kitchen floor."

There was a heavy snow the day of Kathryn's funeral. Chief Baker did his best to force his masonry truck through the drifts to reach the family and to bring them to St. Barnabas in time. But the service was just ending as they arrived. Cecil would have understood. He would have sensed the operation of the power that had always thwarted him. 


\section{Rate Of Change}

$\mathrm{W}$

e are sometimes so overwhelmed by the change in the world around us that we tend to discount the fact that it has been going on for the whole span of our American history. Five biblical lifespans take us back to the Plymouth Pilgrims. The overlapping lifetimes of Einstein, Darwin and Watt reach back nearly to Newton.

Rising before the sun this morning, I read the memoirs of Capt. A.T. Mahan published in 1906 by the New York firm for whom I am writing my own. Mahan saw the change from sail to steam in the U.S. Navy. He saw the day when grog was abolished and a disgruntled captain hoisted a demijohn to the mast top. He lived through the terrible years when friends and brothers were separated by the War of the Secession. He saw the Navy become the agent for American imperial expansion into the Caribbean and Pacific.

Mahan could look back at a time when, during Porter's expedition to the Pacific, the young Farragut could be made prize-master of a captured vessel off Valparaiso at the age of 12 years. Upon Farragut's first order, the old captain was so enraged that he went below to get his pistols, but the young officer's threat to throw him overboard subdued him.

A pilot takes bearings abaft the beam as well as forward to plot his course and speed. That is what reminiscences are all about. Looking backward gives us some sense of direction as we hurtle into the future.

The steps are large: that from sail to steam perhaps greater than that from steam to atomic power; that from sailor to seaman greater than the transmogrification of seaman to seaperson. Those familiar with the use of computers for numerical integration will know that if the forward steps of the calculation are too great the procedure breaks down. There is a critical size of step for which the forward-headed calculation can be both stable and economical. To the extent that our human progress can be thought of in these terms, it seems that the Bible's three-score and ten is right on the button. 


\section{Changing Manners...}

$\mathrm{O}$ ne of the happier aspects of change on the Cape is the improvement in public courtesy. Scarcely a day passes without someone wishing us a good day. It was not always so. A visit to a repair shop or one of the stores in town might mean an encounter with a Cape Cod Grouch. Even a public hearing at town hall might subject you to the domination of a presiding officer whose manners were those of Lionel Barrymore at his most cantankerous.

Many years ago a young couple had some business to transact at the Registry of Motor Vehicles in Hyannis, then housed in a tiny storefront. It was late in the day, and the clerk locked the front door after they had entered. When they had completed their business the wife politely asked the clerk to unlock the door so that they could leave. There was no answer. The clerk officiously shuffled through his papers and made no move to open the door. It was only after the husband in his thickest Texas drawl said, "Stand back, honey, while I shoot the lock off this door," that they secured their release. Today it's so friendly there that they call you by your first name.

Once I accompanied a visiting Washington dignitary to a local restaurant for breakfast. He was an affable man, and as he ordered his coffee, toast and scrambled eggs he said, "It's a lovely day, isn't it?" The coffee mug came, but no reply. With the toast he ventured, "That certainly is good coffee." Finally the waitress placed the rather watery scrambled eggs before him, and he tried once again with, "This is a nice restaurant you have here." And then she said, "Why don't you just shut up?"

I suppose that we are more comfortable with the new courtesy, even if it is impersonal and automatic. Encounters with the Cape Cod Grouch were not so pleasant, but they were intensely personal. Maybe we are missing something in our lives today. It takes vinegar to make a salad. 


\section{Even For A Good Cause?}

Quppose one day you were to receive a personalised (by a computer) let$\boldsymbol{N}$ ter from the International Brotherhood of Customs Inspectors asking for a contribution to their continuing efforts to subdue the drug traffic, to their favorite charity, and offering some handy little decals for your luggage in exchange. You might wonder where they got your name and whether they would keep track of who didn't pay up. Your instinct might suggest to you that public officials, no matter how respectable, ought to refrain from even the appearance of coercion.

If the Guild of Boards of Assessors asked you for a contribution, would you scent a faint odor of compulsion, even if your common sense told you it was not there? What about a solicitation from the Sisterhood of Meter Maids and a sticker for your windshield? While we are imagining things, suppose the Association of Internal Revenue Agents circularised you for twenty dollars, which you could itemise as a deduction? Would there be the slightest presumption of promise of preferential treatment even to the mind of a person sufficiently uncertain of the legal and ethical realities to feel insecure?

Unless there has been a unique mailing-computer accident I must not be the only person in town who received such a letter, on behalf of the Massachusetts Chiefs of Police Association, asking me to send $\$ 20$ for a sustaining membership and offering a " 1985 membership card for your wallet and a window decal for your car." Surely this must be a good cause, and some of the money is even promised to go to a well-known charity.

Law enforcement officers are inevitably viewed with some ambivalence by the public. They are seen not only as protectors, but also as potential adversaries. They may seem at times to be intimidating, and they exercise a degree of discretionary power over us. It is unsettling to think that the message of this letter may be misinterpreted by some who receive it. Is it wise for those employed in law enforcement to solicit money and to offer easily recognisable tokens-even for a good cause? 


\section{Sailor Of The Old School}

A rvid Karlson came to the Oceanographic as second mate on the sea at an early age on board the great square-rigged ships of the Australian grain trade. During the war he served on tankers, and he was never far from the sea.

Like many of the marine staff he wasn't widely known in town: he lived in Providence during his brief spells ashore. But he was a teacher and a legend to the younger crew members and many of them, now nearing retirement, learned their seamanship at his side.

He was a quiet, large man, bald-headed and with a sailor's squint to his eyes. His hands were large, rough and stiff from years of clewing canvas and hauling lines. His accent was heavy, slow and spiced with color, as when he described weather as "mountainous seas and crazy scenery."

Eventually he was promoted to captain of the Caryn, a small and elegant yacht built originally for a British admiral in Singapore, that had found her way to join the sizeable Oceanographic fleet of small vessels of those days.

Captain Karlson was never comfortable on soundings, as I found when I once took the Caryn up to Kennebec, anchoring her at various points to measure the tidal currents, temperature and salinity there. When we had left Seguin Island astern and headed to the open sea, he sighed with relief. One thinks of him patiently sewing the great sails, or splicing rope or capturing someone to play his daily game of cribbage.

He died at his Providence home on Oct. 18, 1955, and his loyal seaman friends saw that his ashes were scattered at sea-at a point off Bermuda where for years after those who remembered him would sometimes pause and pour the appropriate libation of Methuselam rum into the sea. 


\section{An Excessive Show Of Force?}

$\mathrm{T}$ hinking I might be able to scrounge a lobster, I went down to visit my fisherman friend Ken at the town dock this morning. I found him in his galley with his young wife and son gamming with an engineer who was trying to diagnose some vibration in the tail-shaft. He was talking about a Coast Guard search that he had undergone the day before, and it distressed him.

"We were headed in toward New Bedford against a northwester that was kicking up a chop in the bay. We had about 40,000 pounds of cod in the fish hold after five days dragging on Great Round Shoal, and I was hoping to arrive early enough to get a good price at the auction. Then this Coast Guard patrol craft hailed us and ordered us to stop. It happens all the time these days-do you know what they are like?

"They come along side with several crewmen pointing shotguns at us. They order me to the bow and the crew to the stern. Maybe their boat bumps you hard, and one of them lurches against the deckhouse and you think, Christ! I hope he has the safety on.

"Now don't get me wrong, I'm not against the Coast Guard. They have a job to do, and it's reassuring to know they are around if your engine room catches fire on one of those freezing February nights on Georges. Then they'll do their best to help you out. But this business with the shotguns.... Someday some fisherman here is going to be mowed down by mistake. And, frankly, what does it do to a man's sense of self-respect to be paraded in front of those guns every few months?"

I came away with a lobster, and I knew I wasn't going to confront a police shotgun blockade on the way home. No sane person can relish the thought of the awful finality of a nervous trigger finger. There is such a thing as an excessive show of force. 


\section{The Friendly Road}

$\mathrm{O}$ ur first roads wandered from farm to farm, passing often between the house and the barn. The infrequent traveler announced himself from afar as he scattered the hens and roused the old dog. The road was a friendly thing. Little girls, learning their needlework, made samplers with the motto, "Let me live in a house by the side of the road and be a friend to man."

Europeans remarked upon how open small American towns were-no gatekeepers, no high walls with broken glass on the top. And when the weather was good, people would sit on their front porches facing the street to watch their neighbors walk by.

Automobiles intruded. To get away from the noise, householders retreated to their backyards. Some residential layouts were designed for restricted access with checkpoints to exclude the idly curious on their Sunday afternoon drives. For most of us there are few moments free from the sound of an internal combustion engine of some sort: a truck, a lawnmower, a chain saw, an airplane overhead. Real silence is a luxury, even on Naushon.

Much of the old American openness remains. Our houses are not barricaded against the street as in a French village. They are outwardly attractive, even welcoming with their lighted windows at Christmas time. The sense of invitation is doubtless illusory, but it is a sign of neighborliness and trust. The balance between neighborliness and privacy is a measure of the civility of our society.

Our sense of harmony is ruffled when a new neighbor posts his lot with "No Trespassing" signs, or when an institution from out of town acquires a summer property and erects a black iron gate upon its driveway. We have no intention of intruding, but somehow it hurts to be bluntly warned to "Keep Out." These are compensated for by more friendly signs. The recreational use of the roads by joggers and bicyclists humanizes them. We see that real people use them after all. It seems that we can never altogether forget our love affair with the open road. 


\section{Anglers Beware}

The scientific establishment in Plymouth, England, has similarities to our own: marine biologists and a public aquarium, operated under a nominal license ( $\$ 9$ a year) issued by the Plymouth City Council. According to the editor of the Western Morning News (Dec. 12), that is going to change because of the new Zoo Act, which requires frequent inspection by officials of the Environment Department from London-the public, of course, bearing the expenses of their travel and paper work. The new Zoo Act, according to the editor, contains certain provisions to prevent cruelty to fish, and there is question as to whether it extends to household aquaria and goldfish.

Our own legal system owes much to that of Great Britain, and the underemployed lawyers who man our Environmental Protection Agency are quick to pick up new ideas from abroad. Will we see teams of them spending the summer in Woods Hole to keep an eye on the aquarium? Can we tolerate eccentricity as easily as our British cousins do? Sport fishermen and anglers beware! 


\section{Whittlings}

When my grandfather was a schoolboy in the little eastern shore village of Bishopsville, more than a hundred years ago, he learned the fine art of sharpening pencils with a pen knife, an accomplishment that he practiced in his law office until 1932. The secret is to support the point with your thumb and draw the blade toward it with the same hand. In my school we used small patent sharpeners with a fixed blade, tangential to the side surface of a conical hole. They were never quite so perfectly sculpted as his were.

The names in the old family Bible are written in a handsome hand. From time to time I purchase one of those calligraphy pens at an art store to try my own hand, but I can never do so well. Years of typewriting have confused my fingers. Now the word-processor has arrived, and it is confusing my brain as well. With the built-in, self-correcting dictionaries I can even afford to forget how to spell.

The grocery clerk's pride in mental arithmetic has vanished with the pocket computer. Sales of books on chess have dropped now that we have cheap machines that play it better than we can hope to. A power failure can bring the work of an entire office to a halt. And how could we discuss the moral problems of the world without the prompting of Morley Safer, if our TV antenna is blown off the roof?

We have become the beneficiaries of an intricate technological li f e support system, with artificial hands, eyes, brains and thoughts. Our conversations are like echo chambers, reverberating with earnest ideas implanted in our subconscious by the media. Seldom is heard an original word. And if there is any parallel with what has already happened, we may give up thinking too.

When I learned some years ago that the data for the U.S. Census of 1890 is no longer available (although that for all other decades is), and that the Hollerith punched card system had been introduced into the Bureau of the Census at that very time, I thought this surely must have been the greatest computer crash of all time. Upon enquiring, I was assured that the data had been destroyed in a fire, not by some programming error. Perhaps it was just too early on for that to happen. 


\section{Not Afraid Of Life}

$\mathrm{O}$ $\mathrm{n}$ the afternoon of Jan. 7,1975 , the wind came up in the Gulf of Maine. By evening it was from the northwest at 40 knots. The water temperature was 40 degrees. The little research vessel Gulfstream was unable to radio for help and foundered with all on board. During the next few days an extensive search recovered the body of one of the crew of five and a few bits of flotsam. The cause of the tragedy remains unknown.

Among those lost was William Richardson, a good friend of many at the Oceanographic since the early 1950's when he came to Woods Hole with a fresh Ph.D. in physical chemistry from Harvard. Bill first worked on the development of infrared sensing of ocean surface temperature from aircraft and later on the early stages of moored current meter instrumentation. His unceremonious and informal ways earned him the friendship and respect of those who worked with him. He was also independent and outspoken, by no means a tame spirit. In the early 60's he set up a new lab at Nova University where he could be his own boss and undertook an outstanding series of measurements of the fluctuations in strength of the Florida Current.

As a naval aviator at Midway, Bill had experienced the anguish of seeing his entire squadron wiped out in battle. He claimed that from that time he could never again take seriously the petty worries that bedevil most of us: financial security, job advancement, health, academic prestige. He tended to discount his own personal safety. When a crew member fell overboard on one oceanographic cruise, instead of calling to the helm or throwing over a lifeline, Bill plunged instantly into the sea to rescue him: rare courage.

Bill found people endlessly entertaining; he liked adventure and working at sea and in aircraft and the kind of person one finds there. He had seen death so close that he was not afraid of life. 


\section{The Woods Hole Mice}

T $t$ can hardly have escaped the notice of those who pass Woods Hole School that the traffic signs depicting an adult and child holding hands have been transmogrified into mice. It is a Beatrix Potter-type whimsy, and one hopes that town officials do not take them down. The mice are neatly rendered, with circular ears and nicely drawn tails. Let us proclaim them the Woods Hole mice.

From my own years of experience in painting pictures of mice I can attest to the sensitivity of the hand of the unknown artist who created the Woods Hole mice, although my own taste runs to pointed ears. Of course they were hastily executed and under some stress. One hesitates to call their delightful appearance an act of vandalism. The tourist business of some Swiss towns depends upon such attractions. Think of Bern's Kindlifresser. As works of art they must qualify under the new state law that makes it a crime to alter or destroy one. Not even the owner himself may do so, and presumably this applies to the town.

We are reminded of the War of the Signs that raged in Woods Hole from August to October 1952. It was during the period of straightening of the road at the head of Little Harbor. The state erected large signs extolling the new highway system, with Governor Dever's signature reproduced. Some Woods Hole residents objected to the signs as an improper form of electioneering. Protesters uprooted signs and splashed them with paint. One sign was found attached to a navigation beacon.

Each time the state replaced a sign, it was smeared again-and both local and state police were posted to guard them at night. The offenders were first collared when a paint bomb backfired and left the fleeing culprit green-handed. Judge Swift fined him for the cost of the damages and placed him on one year's probation; curiously enough, he was the author of a 1948 book titled Boy Gangs of Mousetown. His brother, a professor of anatomy, received a lighter sentence.

As the weeks passed others took up the fight; more signs were defaced; concealed detectives played cat and mouse in the parking lot of Challenger House, and more culprits were apprehended and tried. And then as the election came closer the state suddenly decided to forget the whole affair, and the signs were left to their own fate. Perhaps it had all become too ridiculous for a candidate for reelection to pursue.

All in all, 31 separate attacks had been made on Govemor Dever's signs. Collections were made at a Woods Hole bar and by the management of the Breakwater Hotel to reimburse the fines, and a fund raising ball was advertised. 


\section{Toll Free}

sleepless rail traveler to Washington, tossing in his bunk on the Owl, A might be startled by the illuminated sign of the Mystic Power Company as it loomed into sight-there was something wonderfully ambiguous about its meaning, as one lingered on the edge of dreams.

The new toll-free telephone directory offers some similar tantalizing items. Because of the matricide of the telephone company you may not get much help from the local company in obtaining it, but a call to 1-800-2424634 , ext. 32, will get you one. A pleasant lady in Minneapolis will take your credit card number, and for $\$ 6.25$ a copy will be in the mail.

A quick perusal will show you that the whole idea of toll-free numbers is still experimental. Businesses and government agencies are uncertain as to whether to attract free calls. For example, the Peace Corps is listed, but not the FBI. Many airlines and the Greyhound Bus Company are included-and several members of Congress are listed.

Some restrict access to a toll-free call from limited areas-apparently you can reach Federal Express toll-free only from Oklahoma, and the Coast Guard recruiting service accepts calls only from the midwest. Other outfits are bolder-the Los Angeles Police Credit Union will accept calls from anywhere in the continental United States and so will Harrods of London, as well as the Anti-Piracy Association of America and the Fort Knox Bullion Company.

The Harvard Coop is there and so is L.L. Bean-under "L," not "B." Apparently if you are moved to call the Founding Fathers, Motor Sheep, Loving Touch, Gay 800, In The Swim, Cherry Cherry, Instant Replay, Total Access, the World of Speed or the World of Stone, they will welcome your call.

Years ago, when I lived in Lexington, where they do not have public trash collection, I used to muse upon the name of one of the local commercial rubbish collectors: The Minute-Man Disposal Company. What good use the British might have made of it two centuries past. But then it does not have a toll-free listing yet. 


\section{A Sense Of Loss}

$\mathrm{A}_{\text {my place fell across the stone wall into the road and caught one of }}^{\text {few }}$ the neighbors passing in her car. Ever since then I have had a wary eye on the bigger one near the house. Almost 20 years ago a tree surgeon examined it, pronounced it diseased and installed some drainage tubes at the base. But in the springtime it was so beautiful, with its great candelabrum of white flowers, that I tried to forget what he diagnosed. It turned brown ominously early every fall, but children used to treasure the nuts beneath it, and one could not question that it belonged there, where it had stood for so long.

Then last spring a great bough from a maple crushed a horse shed out back, and I began to have visions of what that chestnut might do to the house-so while my wife was away I had it cut down. It didn't take long - the branches quickly turned to cordwood, the great sections of the trunk, more than a yard across, stood mournfully about like those Victorian umbrella stands made from elephant feet that used to accuse you as though you had shot them yourself. And the trimmings all disappeared discreetly into the maw of the chipper.

I tried to count the rings, to assess the enormity of what I had done. I guess they numbered about 140 years of growth, but toward the center the heartwood was all spongy. I have awful doubts that it was so sick that it should die. I have cleared it all away, but the unfamiliar gap remains and makes me sick at heart.

Myriads of trees fall every day, some far grander than my chestnut: great redwoods and Douglas firs. Few of us trouble our night's sleep by dreaming of them trundling to the mills. But the thought of what I did to that stalwart old tree, that stood protectingly beside my house when Fillmore occupied the White House and shed its gentle grace upon our corner, makes me grieve. 


\section{Who Would Have Guessed?}

$\mathrm{O}$ $\mathrm{n}$ the first of January two hundred years ago, a Saturday, the London Times issued its first newspaper (under the name of The Daily Universal Register) at the price of two-pence halfpenny, just one halfpenny under the price of its seven competitors. One large sheet, folded into four pages with four columns each, the fledgling Times was printed using a technological innovation called logography, in which frequently used words were cast as single types, somewhat as ligatures are today. The process called for extra-large type cases. As the publisher himself boasted, the arrangement of these cases for the efficiency and convenience of the typesetter presented a problem of "inconceivable difficulty," which evidently he solved.

Of the sixteen columns, nine are devoted to advertisements and announcements of departures of ships to foreign ports, items of salvage, theatrical performances, health studios, stock and bond prices, Mecklenburg cloaks for those "Ladies whose tender and delicate constitutions will not permit them to take proper exercise in the winter season" and divers sales by auction and by candle. And the public is invited to Buzaglo's, opposite Somerset House, to meet persons of distinction who have been cured of Rheumatism, Gout and Weakness of the Limbs, and who will vouch for his novel course of treatment.

The publisher, J. Walker, reserved three columns in this first issue to introduce himself and his editorial policy and philosophy, which he promises will be nonpartisan and fearless. He will accept any kind of advertisement, providing only that it is legal. An abstract of the proceedings of Parliament will be a regular feature, and above all the news will be fresh, not warmed over and stale.

Then there were two columns of Foreign Intelligence and a column about the trial of a bankrupt before the Guildhall. And finally an entire column written under an assumed name, very likely by the editor himself, in which it is asserted that "the defects of newspapers bear no proportion to their beauties"-and apparently proves it by printing half a column of jingo poetry. During its first few faltering weeks, who would have guessed it could last 200 years? 


\section{Genie Of The Lamp}

Ometime back in the fifties I remember reading one of those "How's that again?" space fillers in The New Yorker that ran something like this: "Beulah, Iowa, Eagle: Bayard Tewksbury of Cat Corner Farm has received a brand new pickup truck from the Ford Motor Company in exchange for his 1928 sedan, which despite hard usage, and 300,000 miles of travel on our back roads, has never required the repair or removal of any part, and is still running perfectly. The company engineers are shipping it to Detroit where it will be completely disassembled and every part subjected to the closest examination to determine why it has stood up so well so long." To which The New Yorker added: "and to be sure that it never happens again."

I have a similar story of my own, but have been reluctant 'til now to make it known. The Earl of Chesterfield, whose letters to his son were full of good advice, once wrote: "Had I seen anything so very extraordinary as to be almost incredible I would keep it to myself rather than by telling it give anybody room to doubt of my veracity." Well, here goes.

I am writing this letter by the light of a fluorescent desk lamp that I purchased at the Yale Coop in 1941, and I have never had to renew the tube, despite 44 years of intermittent use. I didn't think you would believe it. In fact, the sturdy little lamp is so anxious to keep burning that you have to push the button at the base of the lamp several times to get it to turn off.

Does anybody remember some controversy long ago over the original coating of these tubes? Some question of their being deadly poisonous and their being recalled? Unlike that Iowa farmer, however, I'm not going to exchange - not for all the new fluorescent tubes in China-the little Genie of my lamp. 


\section{Access...}

Thave been driving up and down Sippewissett Road for about 35 years, 1 maybe on the average about twice a day. That multiplies out to a pretty big number. For the first decades the road was spared the rapid development that has overtaken other parts of town, but now its time has come. The "Places" and the "Highlands" have arrived and variously cutely named "Drives," which will commemorate, ironically, the names of their despoilers.

There is nothing particularly unnatural about the way humankind spreads over the countryside. An overripe peach is quickly covered with mold, beavers fell the trees, the farmland of Roxbury is no more. There doesn't really seem to be any way to stem the tide of our acquisitiveness. But what might be avoided is the way that public access to old roads and pathways to ponds and dunes, to woodland lakes and to the beach is continuously being restricted and cut off by sudden assertion of the rights of private property over ancient, but undocumented, rights of way.

As the large house that dominates Miles Pond approaches completion, it is probably irremediable that the old carriage path to the Beebe Woods from Sippewissett Road, open for so many years along the northern edge of the pond, is now barred to the pedestrian. It is entirely consonant with our American mores that beaches and the littoral of ponds can be privately owned. The Swedish mores that dictate public access are not yet ours; not even the British reverence for ancient ways.

One wonders whether there is in this town the wisdom and the will to find a way to reopen some pathway from Miles Pond to the Beebe Woods. Is there someone in Marvin Gardens, or along the way, who'll offer an easement for a footpath? Would the town offer, in return, a reduction in his taxes? 


\section{Counting Our Blessings}

$\mathrm{O}$

ur attention is so directed by the media towards the shortcomings of our society that we often forget to count our blessings. One that particularly comes to mind is the Falmouth Hospital, which but for the efforts and devotion and vision of some of our physicians and citizens might never have come to be.

Only a few short years have passed since we had to rush to Wareham or Hyannis in an emergency, and now, seemingly miraculously, there it stands-a secular temple of care and kindness and medical knowledge. There is something comforting and homely about a community hospital: faces known for half a lifetime, the nurses with whom your own children went to school. And all of this, grown out of the good intentions of our neighbors great and small.

It was not always so. About fifty years ago, in the mid-thirties, a little girl and her brother on Shore Street came down with what was diagnosed as infantile paralysis. Dr. Oscar Simpson, who used to live in a redtrimmed white house where Li'l Peach Grocerette now stands, tried to arrange for the town ambulance to take the pair to the Children's Hospital in Boston for further examination.

Polio was then viewed with the same fear that AIDS is now. It seemed that no one was going to volunteer to drive the two children down to Boston-but finally one fireman stepped forward to take the risk. It must have taken considerable resolve and courage for anyone to contemplate the possibilities of infection, especially for a father with children of his own.

It is one of the redeeming features of our human race that, when everyone else wrings his or her hands and turns away, there is always someone else who stands firm and does the needed job. We have our splendid hospital now, largely through the devoted efforts of a few. The town ambulance sped to Boston on its mission of mercy those long years ago, on account of one man's courage and generous heart. He is my neighbor Stanley Fisher. The little girl is my wife. 


\section{A Day To Remember}

Tmmediately after the war, when memories of cheap gin and whiskey at the IPX were still fresh in the minds of many oceanographers and our little ships began to venture out to Bermuda and the Caribbean again, it was comforting to find similarly low prices at the saloons and liquor stores there.

The lack of motor vehicles on Bermuda, other than motor-assisted bicycles, ensured that the victims were usually the drunks themselves, and the authorities there were complaisant, compared with their attitude today. Nearly every other week some tipsy airman from Kindley Field would ride his bicycle off a cliff, but no one seemed to mind.

When one oceanographer, in his cups and tired of waiting for a bus to depart, drove it off through the narrow streets of St. Georges until he finally wedged it so tightly between the building walls that he couldn't get out, he only had to spend one night in jail. Even the magistrates at Hamilton shared in such escapades.

One morning issue of The Royal Gazette carried an account of the Worshipful Mr. Minty being arraigned before his colleague, the Worshipful Mr. Godet, and fined five pounds for taking someone else's motorbike on his way home from the bar at the Dinghy Club. Immediately after the sentence, Mr. Minty was brought before Mr. Godet, who proclaimed, "This is the second time such a heinous crime has been brought before this court this morning. Ten pounds."

\section{Smuggling Rum}

It was not surprising in such a relaxed atmosphere that oceanographers would pay a visit to Gosling's for an $\$ 8$ case of his Choicest before departing to Woods Hole, and if they did not consume it all, bring it home, undeclared, in their duffels, to warm a cold, wet February evening ashore.

Smuggling rum "for personal use" became so much a tradition, generously overlooked by the inspector from New Bedford's Customs Office, that it was frequently considered to be one of the fringe benefits of Woods Hole's work at sea.

If there were a few who viewed it as a moral outrage, there were many more to whom it seemed as fair as letting the tourists take home a gallon duty-free, even if in their own case it wasn't exactly legal.

This happy state of affairs might have gone on indefinitely had it not been for a gradual increase in the volume of liquor imported, the result of requests from the office staff for some cases of their own. And who could refuse a retired engineer a few bottles of his favorite medicine? Although an open secret, it was not so clearly perceived how large the sum of all the small violations, stuffed under every bunk, could seem when toted up by a remorseless head Customs inspector. 


\section{A Day To Remember}

For the time of year Sunday, March 20,1960, was a pretty nice day. The Fesearch vessel Crawford slipped quietly into her dock, and was cleared in routine fashion by the Customs inspector from New Bedford. The scientists and crew dispersed to their homes with such equanimity that many left their cases of illegally imported liquor under their bunks with their names on them.

A few rather large strangers-retired pugilists perhaps?-had been seen lingering around Water Street, but no one gave them a second thought.

And then suddenly an armed enforcement squad led by Chief Inspector Edward L. Finnegan from the Boston office descended upon the dock, impounded the ship and two private cars that were employed in a private loading operation there, and whisked away all the whiskey.

The Chain was due in port three days later, and would have suffered a similar fate had not someone found a way to forewarn her. The decision was made to declare the considerable number of cases on board, under bond, even though that would mean it could not be landed. The lawmen found a technical reason to whisk away all of the Chain's cargo as well, but no proof of criminal intent.

The mills of the law grind slowly, and for months there were many anxious souls in Woods Hole. The individual fines were moderate, the liquor was gone-although Customs kindly offered to let us buy it backand the heavy fine levied on the unfortunate captain was shared by those concerned. One of the autos was returned, and in time the Crawford herself released. Ironically she had begun her career as a Coast Guard patrol vessel during Prohibition and had taken her own toll of "Demon Rum."

We used to wonder what caused the boom to fall, and why on us? Perhaps it was the far larger illicit trade at Otis, which Customs had decided to warn indirectly through making us a lesson. Perhaps it was a simple matter of inter-regional rivalry within the Customs itself-a matter of Boston over New Bedford. Some speculated that one of the local liquor dealers had turned informer. If it was who we thought it was, he redeemed himself with a generous bequest to his church.

Twenty-five years have passed since those days of guilt, shame and regret. We don't feel like criminals anymore. Why, there may even be a sentimental party to commemorate the event somewhere in town, this coming March 20. 


\section{Gambling Frenzy}

W hat must have been the single greatest night of gambling in Woods Hole history occurred at the Episcopal Rectory nearly forty years ago. Hundreds of millions of dollars changed hands before midnight-and this was in the days before there was even a thought of a state-sanctioned lottery. The minister himself was not directly involved. He was living several houses removed and had rented the old rectory to some Woods Hole bachelors.

Up to the particular night involved, gambling at the rectory had been confined to the modest weekly poker game with Jeff Allen, Bill Schroeder, Art Klebba and a few guests. But on the great night itself the house was crowded, mostly around the roulette wheel in the parlor. There were card games in the second-floor bedrooms and a very serious session of 21 on the third floor. A bank adjoined the bathroom. It was stocked with bills of various denominations, from one to a hundred dollars. A few bills with higher denominations were held by the bank in reserve, and of course the old gelatine hectograph, green ink and extra paper stood ready should more currency be required.

Upon arrival each invitee was issued some of this cash, free, and steered toward the gambling tables. Anticipating that there might be a shortage of low denominations, the bank offered larger ones for small ones at the rate of 10 to 9 . Timid souls spent the evening collecting one dollar bills and exchanging them for 10 dollar bills--a steady if modest profit.

The pace at roulette was brisk. Dave Barnes, the croupier, insisted upon carrying a thousand dollar bill for emergencies in his back pocket. Gil Oakley, captain of the Atlantis, deftly filched it, placed it on a single number, won, and the inflation was on. Rapidly the bets increased; the bank printed bigger bills; the passion of greed mounted, and by one $o$ 'clock stakes of millions of dollars were on the table. The faithful few at the 21 table upstairs, including, as I remember, Andy Bunker and Phil Shafer, were playing for a hundred million dollars a hand.

Altogether it was a remarkable evening, perhaps uncomfortably a little too much like real life. The fever of winning, the smell of money, the lure of quick profit, a certain mad recklessness permeated the air. If a toy printing device can evoke such frenzies, think what the U.S. Treasury's Bureau of Engraving is doing to us all. 


\section{Love Of The Land}

W hen the Quakers first came to Sippewissett as a refuge from Puritan persecution, the land that they purchased from the Indians extended in long narrow strips from the fresh water of Long Pond to the salt marshes along Buzzards Bay. Their love of the land was deep in the heart of Sue Moore Sisson. Her husband Fred, a gentle artist who had studied under Abbott Thayer during World War I, had taught painting at the Rhode Island School of Design before retiring without pension.

He shared her passion for things beautiful. They built with their own hands the house now owned by the Waterburys; they cultivated a lovely garden, and they were gracious and generous neighbors. I will always remember their forebearance after we had acquired her father's house as we, in our ignorance, tore up the peonies and poppies they had so lovingly cared for in our garden.

When Fred's heart failed him in 1962, she lived in desperate loneliness with memories of their year in France. Our children were denied television at home but were welcome at her house. Sue would conduct them to her parlor where they could turn it on. She would pour herself a large bourbon, and when she began to snore they would switch it to the noisy program they had come to view. She gave them refuge from the restrictions of our home. They gave her their company.

Like many old Cape Codders she abhorred the notion of selling off her land. Her memories of family excursions to the marshes of Sippewissett, of their filling pitchers with cool water from the freshwater spring there, and of their father sternly asserting his right of way despite the scowls of old farmer Will Gifford as they made their way across his pastures to what is now Sippewissett Place were too strong to permit her selling it off. Sue died in 1971.

Their only daughter married the land developer who invented New Seabury. And when she too died, he had her Sippewissett land auctioned for the benefit of her grandchildren. It is now crowded with houses.

When I read about the efforts of our fellow citizens to preserve the open land of Falmouth, I think of the lifetime resolve of Sue and many others to keep it so. We have 600 feet of roadside now devoted to lawn and an untidy garden. I pretend that it is a "farm." All around me developers are offering deep-lot frontages at $\$ 700$ a foot. I think that I have some idea of the pressures that Sue Sisson withstood. 


\section{On Honorifics}

Walf a lifetime ago, when I still felt flattered at being addressed as pro1 fessor, I happened to be invited to a friend's house in Coconut Grove. I stopped on the way at a neighborhood liquor store to purchase a present of a Greek apéritif for his wife. The owner was busily checking some invoices on a newly arrived shipment, and I complimented him on the variety of his wares. He explained that he was a professor of beverages at the University of Miami-an academic career the possibilities of which I had somehow never considered.

Time was that the only doctor in town was a physician. Very occasionally one might encounter an eminent divine sporting a D.D., but a nonmedical doctor was something of a rarity. Woods Hole was, of course, an exception. Then, as part of our national response to Sputnik in 1957, there was a vast expansion of our graduate schools. A Ph.D. became necessary for entrance into a career of government-sponsored research.

Today there are probably more Ph.D.'s in Falmouth than there were B.A.'s two generations ago. At a recent hearing it was asserted that one housing development is exclusively inhabited by them.

Sometimes it leads to confusion. Years ago I was staying at the home of one of my oldest friends and mentors, author of a distinguished treatise on physiology. He has done fundamental research on hemoglobin. Before he turned 80 his days were filled with adventure: a pack trip through the mountain passes of Kurdistan, or a solitary perambulation through the jungles of New Guinea with two paroled cannibals for guides. For several years he once paddled a kayak back and forth between Woods Hole and Stone House on Naushon every night during the winter. Today he lives and works in Rome. He is a Boston patrician of the old school and, I think, the wisest man I know.

It was after dinner, and we were sitting in the parlor of his house in Chestnut Hill, next door to the Cabots. He had recently lost his wife, and conversation seemed to do him some good. The telephone rang faintly in the hall, and we could hear the maid going to answer it. "Yes, this is Doctor ...'s residence." A pause, and then in her thick brogue:

"Oh no, Mam-he's one of them doctors that never does anybody any good." 


\section{When Science Failed}

$\mathrm{O}$ n Fridays at five o'clock Columbus Iselin used to leap aboard the Risk to retreat to his farm at Tashmoo, leaving distinguished visitors to fend for themselves. They frequently ended up at the rectory for room and board. The Antarctic oceanographer Sir George Deacon was eating spaghetti in our kitchen on the Saturday that we discovered that the gas that gurgled up from the drain in the sink, when the plumbing upstairs was used, could be ignited in a clear blue flame.

Fearful of a subterranean explosion, we decided to remedy the matter and systematically probed the yard with drill rod to no avail. The resources of science were brought into play. Allyn Vine loaned us an old mine detector, but we didn't seem to be able to make it work. Johnny Holmes devised an electrical potential method, in which a perilously high voltage was applied to the sewer pipe where it left the cellar. A map of the voltage field out back would, theoretically, lead us to the offending pipe or cesspool cover. Somehow it didn't work either.

The desperate measure of digging down to the pipe where it was known to leave the cellar and trying to follow it came to an end when, after twenty feet, it appeared to go straight down. The methods of exact science having failed, we turned to the occult.

A visiting biologist, Dr. Hillary Moore, had often aroused our skepticism with stories of water divining in the west of England. He offered to solve our problem. As we walked toward the rectory past Little Harbor, Hillary broke off a willow branch from a tree in Frank Ryder's yard. This brought Frank out of the house, where a ladies' tea party was in progress. They all followed us to the rectory's backyard, where Hillary paced up and down delicately balancing his willow fork. As we turned on all the faucets and flushed the toilets to stimulate the power of running water, the purer scientists Art Klebba and Andy Bunker retreated upstairs with a bottle of Scotch. When Hillary finally felt the proper twitch, the twig was pointing directly at the center of the concrete garage floor. We expostulated, but old Mrs. Moore spoke up with "I'm sure my son's correct." Then George Clarke's mother discovered, with her cane, an iron cover in the driveway, but it turned out to be an empty rain cistern. The resources of science, both profane and occult, had been exhausted. Even the keen eyes of old ladies had been deceived.

George Griffin, one of the vestrymen, was also water commissioner. He represented therefore the combined power of both Church and State. When he heard of our plight, one of his men with a water-main detector came to the scene. He found the lid in no time flat, behind the garage. We eagerly dug down and, with a bar, cracked it open. There was an immense rush of escaping gas, and our troubles with the netherworld were over. 


\section{Omniphobia}

$\mathrm{W}$ hen the boy chemist Charles Martin Hall graduated from Oberlin College in 1885 he had already invented the electrolytic process that has made aluminum an everyday metal. In the years before Hall's experiments in the college laboratory the metal could only be obtained by reduction with metallic potassium. The process was so expensive that Napoleon had bemoaned his inability to afford it for the mess kits of the French Army.

Hall's subsequent career is Horatio Alger-like. When his newly formed Aluminum Company of America discovered that it had misspelled the name of the metal on their stock certificates (it should be aluminium) they brazened it out and changed the American language.

And now, if we are to believe the TV announcers, aluminum has joined the growing list of substances that "may be injurious to our health." We are told that its use in kitchens causes Alzheimer's Disease, and, goodness knows, they may very well be right. So, mothers, reserve your pots and pans for the dog's dinner; throw out your aluminum foil, and when you travel, fly in fiberglass airplanes. A general fear of toxic metals is sweeping the land.

Uncle Zeb and I were out back, settled comfortably between the cracker barrel and the potbellied stove. From time to time Zeb would direct a jet at the latter, and there would be a spurt of nicotine-scented steam. To our surprise, who should walk in the door but Dr. Hashelew. He seems to have been studying up on "toxics." When there's a new enthusiasm in the air, the good doctor is seldom left standing at the starting post.

"You know," he said, "when the Shakers in Shirley painted their new meeting house in 1794 they used 400 pounds of white lead. They weren't figuring on future generations. What I am going to promote is the prohibition of butter and chocolate. The biggest threat to health in this country today is obesity, and those deadly two ought to be declared controlled substances. I'm going to see them recognized for the killers that they are, and have them added to the Surgeon General's list."

Dr. Hashelew has the facts and the statistics to back him up. We wish him good luck. We think he is on a fair course and the wind is with him. These are times, in his words, when there is an environmentalist born every minute. But when butter and chocolate are withdrawn from the open shelves and banished to behind the prescription counter, I know one renegade who will seek out the pusher near the drawbridge in Woods Hole and purchase a five-dollar chocolate cherry. 


\section{Tilth Of The Soil}

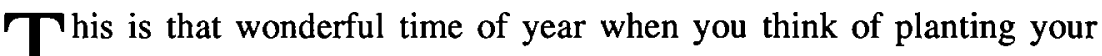
1 peas. The deep frost has thawed, and you are waiting for the soil to dry enough to till. As year follows year, as the residues of manure, leaf pile and seaweed mature, and as what was sand or hard clay turns to that marvellous black friable stuff that streams through your fingers and soothes your soul, your bit of garden soil enslaves you to the land. It has become a part of you.

Some of you will remember Ed Moore, the little man who sat beside the safe-deposit vault at the bank more than 30 years ago. Ed got his pharmacist's certificate in 1901. It still hangs in the old carriage shed. By 1932 he was in the nursery business with Grant Lunn. Their greenhouse is now Elsie's German Sandwich Shop. The stock was grown in Sippewissett. That is how I inherited those nice rows of 60-year-old Colorado spruce, Spanish cypress and the arborvitae.

Looking over a ledger from 1932 one concludes that their business wasn't very brisk. A 30-cent purchase could entitle you to a place in their book; most accounts were less than $\$ 10$, and the biggest customer of all, Walter C. Janney, spent $\$ 1,500$ for the year. The Oak Grove Cemetery was good for half a ton of fertilizer. The old familiar Falmouth names are all there in the ledger, written in a flowing steel-pen hand, rather like a family album.

Out back, beyond the mosquito ditch, Ed had an acre of strawberries. As the nursery business crumbled, he sold the topsoil of his berry patch. For days huge trucks crawled through the muck, hauling it away and leaving a kind of quicksand that has barely healed today.

I look out of my study window to watch more loaded trucks grind by, carrying other people's topsoil to the new housing developments. New neighbor, reflect! Perhaps the earth from which your new lawn sprouts once knew the care and love of a Hatchville farmer's hand and perhaps was cursed by his son who, fed up with weeding carrots, ran away to the Great South Sea. 


\section{We're Over The Ridge!}

Tn the early 50's the IRS was trying to decide whether the National 1 Geographic Society with its ten million members could really qualify as a non-profit scientific society. "Doc" Ewing thought it a favorable moment to ask them for some research funds to sample the ocean bottom near the Azores. Shortly thereafter the magazine carried a colorful article about his success in scooping up some rocks there, and a salty photo bearing the legend "We're over the Ridge!" Recovering anything at all from the ocean bottom impressed us greatly.

Some of us who were wondering whether we could place instruments on the ocean bottom and recover them by dragging thought it might be worthwhile to consult a cableship captain. Our friend, the Marine Superintendent for Undersea Cables at Western Union, Mr. C. S. Lawton, arranged a visit to the cableship Lord Kelvin. Three of us from Woods Hole flew to Halifax, were duly impressed by her size, which dwarfed anything we knew, and ushered into Captain Beady's (as I will call him) cabin.

A small, delicate martinet of a man with, as I remember, manicured nails, Captain Beady politely had us seated and introduced the subject of golf. He must have run a taut ship, because as we sipped his sherry, the seamen, scrubbing down the bulkhead outside his open door, kept out of view: all we could see were their hands with the sponges.

We were interested in the type of grapnel he used, ones that could cut a cable and clamp onto the end desired, even if they tumbled over while being dragged along the bottom. Instead of taking us down to the welldeck he had the crew manhandle them up to his cabin and lay them out for our inspection on an immaculate canvas. It was a lesson in command.

Before we departed Captain Beady enquired whether we were associated with the place that operated the Atlantis. He had read the National Geographic's article. And he had been ordered out to the mid-Atlantic in winter to repair one of the transatlantic cables. Sending the mate to copy out the position of the splice, he said the cable had been probably cut by a rock dredge.

Upon our return to Woods Hole we found in the Atlantis's log that she had lost a dredge at that very position. It caused us to reflect upon the professional precision of his repair as contrasted to the amateur nature of our random scooping up of rocks. It might have been polite to write to him and confirm his guess, but somehow we didn't think the redoubtable Captain Beady really needed to know. 


\section{My Friend John Moore}

$\mathrm{O}$ ne Fourth of July, some years ago, I invited the neighbors to a homemade fireworks display: Giff and Win Ewing, Sue Sisson and Claude Ronne. John C. Moore came, too, from across the street, although, as he said afterward, he didn't think he was going to see much.

The pyrotechnical cardboard tubes were nailed to boards and sawhorses in the old apple orchard-all ready to go. When the first fountain bloomed it spread to the quickmatch on all the other devices, and the entire display erupted in one simultaneous convulsion of strontium-tinted fire. A dense magnesium-oxide smoke drifted across Sippewissett Corner. Giff fell over backwards in his chair. Globules of molten saltpeter ignited the grass. The garden hose was brought into play, and John Moore exclaimed that it was the best fireworks show he had ever seen.

Descendant of one of the first settlers in Sippewissett, John Moore was born in 1884. Qualifying as a marine engineer, he was employed first in the harbor works at Galveston that followed the great flood of 1900 and then on the two-mile-long west breakwater of the Panama Canal at Limón.

Malaria brought him back to the family homestead to recuperate, but shortly he found himself working for an insurance company inspecting factory boilers all over New England. Soon he was back on the Cape again, this time with the water department, of which he was superintendent from 1927 to 1946 . When his brother Ed died he inherited the old family place; when his wife Laura died in 1961 he moved there.

John was one of the best-known men in town, and one of the best liked. Although he lived alone, his days were lightened by the visits of many an elderly lady friend from West Falmouth. Most afternoons there was an automobile in his driveway. He had an open, friendly, boyish manner, an impish sense of humor, already apparent in the family photos of the mid 1890's.

You might find him out in the backyard toolshed, by the wood stove from the Davisville school, deep in conversation with Charlie White, Clarence Anderson or Robert Kahler. His house still shows traces of his eccentric experiments in plumbing and heating arrangements. Some of his old pipe wrenches and homemade power tools that escaped the auctioneer's hammer are still there.

At 81 , John was too frail to survive his colostomy. He was fretful over the tubes that tied him to his hospital bed and anxious to be home again. And I could see in his youthful eyes the utter disbelief of that inner boy of 10 that he was about to die. 


\section{The Western Islands}

$\mathrm{n}$ 1855, when telegraph poles were being erected on Naushon to connect 1 Tarpaulin Cove to Boston via a submarine cable across Woods Hole, "Governor" W. W. Swain wrote facetiously to his friend Charles William Dabney, American consul in Horta, Fayal, that it would not perhaps be long before they were connected by cable.

In time it came to pass, and by the 1920's Horta was a great communications nexus, with five cable companies operating under one roof. Cables ran out under the sea directly to Manhattan Beach, Halifax, Newfoundland, Ireland, England, France, Portugal, the Cape Verdes and Brazil.

It was evident in 1953 that these lines would soon be abandoned, and that they provided a never-to-be-restored chance to measure electrical voltage differences between different parts of the North Atlantic. My traveling companion, Father Freitas of Fall River, and I flew to Santa Maria, and went by bus to Vila do Porto, where in the privacy of the belfry of the church we delivered to the parish priest small presents for relatives from family members in Massachusetts.

The pilot of the interisland airline to Terceira was ill, so Father Freitas managed to hitch a ride for us on a Portuguese Air Force plane to Lajes, where we parted company. Thence overnight by a small schooner, touching at little towns along the beautiful south side of São Jorge, I made my way to Horta and the cable station.

The manager of Cable and Wireless Ltd. was living in the old Dabney house "Fredonia." With the help of the staff I managed to get a good series of voltage measurements: each hour, traffic would be suspended on all the cables for a minute, just time enough to get the readings.

I have visited the Azores in the happier days since, but times were hard in the Azores of 1953. A man working at a fish packing plant earned ten cents an hour, and the middle-aged maids who worked for the families of the cable company-they did all the housework, washing and cooking-received five cents a day.

Time moved very slowly, as often happens on isolated islands. On the ferry to Pico I met an ancient fruit grower who, as a youth, had brought back slips of orange trees from California and now grew them on his mountain side. The news of the world seemed to have passed him by. When I asked him how he had liked America, he replied: "It was very nice, but President Cleveland spoiled it with his free trade policy." 


\section{Time Warp And The Western Islands}

70 the visitor at a New England whaling museum, the whaleboat, 1 lances, spades have the dried disused look of some Viking relic dug up from a Danish bog. Thirty years ago you could still see these tools of the trade clean, limber, perfectly honed and ready at a moment's notice for the great sea hunt-lying in whaleboats on rollers in little villages along the south side of Pico.

The young men there were organized in something like our volunteer fire departments. During the day a lookout on the mountainside watched for signs of whales. Spotting one, he'd fire off a maroon and line up two flags to indicate the bearing of the whale. The boatmen would drop their tools in the fields, roll out the boat and row out for the kill. It could not have been much different in New England two centuries ago.

For some reason the beautiful Western Islands do not attract a significant tourist trade, although from time to time you may encounter a realestate agent escorting a rich German around São Miguel. There are echoes of the old Bostonian connections: the wonderful San Pedro Hotel in Ponta Delgada was once the home of Harriet Webster, where, as the daughter of the American consul she was raised in the lap of luxury. Indeed she acquired such extravagant tastes that when she married professor John White Webster he ran into ever mounting debt-particularly to a colleague, Dr. George Parkman.

On Nov. 23, 1849, Dr. Parkman cornered Dr. Webster in his laboratory in the Harvard Medical School and demanded repayment. Angry words were followed by a blow to Dr. Parkman's head with a billet of grapevine.

Dr. Webster's efforts to dispose of the remains by dismemberment, incineration and deposit in the school's privy were uncovered. The forensic evidence against him was prepared by the most eminent Boston physicians, Oliver Wendell Holmes and Jeffries Wyman. Dr. Webster's plea of innocence, the grisly details of the discovery of the thorax and false teeth and the eminence of those who gave testimony attracted 60,000 visitors to the eleven-day trial, in batches, allowed ten minutes each.

The desperate gentle Professor Webster was hanged on Aug. 30, 1850. According to a recent book by Harvard professor John Millet Rogers, Bostonians with business dealings in the Azores, acting in sympathy with the Websters, managed to keep news of this disgrace from reaching the islands until 1973. And he goes on to say that, if you ask, the San Pedro hotel will put you up in a bedroom with Harriet Webster's family bed. 


\section{Good Investments}

W

ere the ghost of some old New England whaler or sealer to seek the backing of investors in the moral climate of today he might find some difficulty raising the money to harpoon whales in the Great South Sea or club seals of San Fernandes. The public now recognizes that by supporting such enterprise something fine is destroyed.

We wonder when a similar antipathy toward investment in Cape Cod land speculation will become common-it is, after all, a matter much closer to our souls (and purses). The land development entrepreneur does not often work with his own money. He (or she) scans the obituary columns for notice of the death of some old Cape Cod landowner. Like as not the heirs need cash, not a hundred acres of overgrown pasture and woodland. He persuades some Mr. and Mrs. Havebucks who live in the settled "good part" of town that they ought to buy it up, as an investment.

On the edges of the land, some young couples have established home sites-revelling in the privacy and quiet of an inexpensive part of town. They dig a garden, accumulate backyard trash-who would ever notice? They may even keep a pig and some sheep. It is a bucolic setting from yesteryear.

Then one bright morning the land developer pays a call. Perhaps his (or her) investor comes too-and maybe even a friend. They tell the startled housewife that the houses that they're going to build will be very nice, and that they guarantee she will now have friendly neighbors. But the privacy will be gone: the feeling of having a little part of the world of one's own.

Land speculation has an ancient history in our country. Some of the original colonies were begun as land development schemes, for the profit of investors back in Europe. It is older in this country even than the institution of slavery. But it exacts an increasing social and environmental cost.

At some stage, it would seem, means will be found to put it under some effective control. Then it will join those other traditional ways of making money, like pursuit of the whale and the seal, or investment in business in countries with antiquated social laws, ways that at first are recognized as undesirable and later perhaps made unlawful.

Maybe in the end it depends upon the awakening of the public's conscience, beginning with that of the investor himself, who would raise a rumpus if threatened by a marina next to his seaside home but is strangely insensitive to the anguish he inflicts upon the less affluent townsfolk at the back of town. 


\section{Saltwater Soap}

$\mathrm{T}$ he outback of Australia is usually very dry. Once in awhile, however, there is a great downpour of rain, and the plains are flooded.

A friend from Adelaide showed me slides last year of a temporary lake that extended beyond the horizon and had been there for a full year. One envisages travelers who awaken on a morning after camping on a hill during a rainstorm to find themselves surrounded by water as far as they can see and wonders what they do then.

Most years we have our temporary lakes on Cape Cod. The twin lakes on Palmer Avenue that follow every heavy rainstorm come to mind. Generally no deeper than eight inches, they slow down traffic. The cars of forgetful automobilists sometimes stall on the blind curve at Sippewissett corner. Their owners forlornly crank their engines and eventually arrive at neighbors' doors with sodden footwear.

A benign Providence so far has kept following vehicles rounding the curve from ploughing into them, although it is not above occasionally guiding a speeding sports car into a spectacular water reentry. Then the sportsman reluctantly opens the door and steps out into the muddy waters in his best running shoes.

Our temporary lakes have not been much in evidence this springalthough not because of, I think, the efforts of the Falmouth Public Works Department. It is a matter of lack of rain.

We have had a sprinkling or two, but none of those spring drenchers that flood cellars, emulsify the garden and feed our temporary lakes. It has been a good spring for automobiles, but will it be a good summer for us all? One wonders about the water supply once the hordes arrive.

Wondering what precautions to take in the eventuality of a summertime water shortage, I asked Dr. Hashelew what he was doing to get ready. His reply was short and to the point: "Plant your garden with cactus, get a supply of saltwater soap for bathing and doing laundry at the beach and practice washing your teeth with bottled beer." 


\section{Computer Error}

$\mathrm{M}$

$\mathrm{y}$ friend Junius recently was given a personal computer by a friend who decided, after weeks of being imposed upon by his software, that he was going back to a standard manual typewriter-you know, the kind that Smith Corona has discontinued making, and that is still illegal in Bulgaria. Junius got on with it famously, and even keeps his bank account up-to-date on it (in "real time" as they say). The other evening a neighbor's son hit the power pole outside his house, and it seems to have affected the poor thing's memory. Anyway, the next mail brought to Junius a letter from his bank saying that he had overdrawn his account and stipulated a fine.

Junius was outraged, and speedily wrote to the bank manager saying that it had only been a computer error-something well-known to the banking community - and from his past experience a cause that explains and excuses everything that goes wrong. Not so, he was quickly warned. Errors by personal computers don't qualify as excusable errors, only ones by the banks' computers, although they are all made in Japan.

I do sympathize with him. There is nothing one can do about it. On the past April Fool's Day a term certificate based on a loan on my life insurance expired, and my bank withdrew more than $\$ 11,000$ too much to pay back the loan. Only today (May 8) did the amount get refunded to me-I had to fight a protracted series of computer errors and denials on the part of some nitwit in Woburn that there were any errors. Thanks to the personal attention of the bank's assistant treasurer, I did eventually get the money back. If a human clerk habitually made such errors, he'd get sacked. But computers, unless they are your own personal computers, never assume blame.

When I missed receiving three successive issues of The Enterprise in the mail, I was powerfully distressed. After all, I look forward to reading my letters as much as anybody. But the response to my telephone enquiry was that the trouble must be at the post office. A later call elicited the reply that the computer was probably to blame. I hope that the editor administers it a good spanking, and I wonder whether I will ever find another copy in my mailbox. 


\section{High-Iron}

7 his year is the 150th anniversary of the opening of the railroad from 1 Boston to Worcester. The through route to New York City didn't open till a few years later, but already in 1833 ground was being broken for the new line at Stonington, cuts and embankments made across farmers' meadows toward Cranston, the levelling survey being carried forward by a 17-year-old lad, fresh from an apprenticeship at the construction of the Grand Western Canals in the southwest of England.

We happened to find his daybook among some family papers. It conveys the sense of adventure and excitement as the first railroads were being laid out: setting out the pegs, calculating the cut and fill, negotiating with the laborers about their 65-cents-a-day pay.

The chief engineer on the job was Major George Washington Whistler, age 33, who had resigned his professorship at West Point to take up a career of railroad construction. When the Tsar of Russia decided to build a railroad between St. Petersburg and Moscow, he engaged Whistler to do it for him. American companies took over the Alexandrovsky State Factory just outside of St. Petersburg to build locomotives and rolling stock, an early example of technology transfer.

Many of the transplanted American, Scottish and English families continued in business in Russia until they were expelled during the Bolshevik Revolution.

Three weeks ago I rode Amtrak from Wilmington to Boston. The cars seemed as crowded as during the War. It was a leisurely, comfortable ride, and a good chance to renew acquaintance with old familiar landmarks. And though we made our obligatory stops at Old Saybrook and Westerly, many of the stations on the old railroad maps seem to have disappeared. What has become of Slocum, Leete or Wood River Junction?

The railroad mileage in this country increased rapidly until the 1920's, when it first began to decline. At one time there was a mile of track for every four square miles of land area in Massachusetts. Amtrak is the gallant, though tired, survivor. Now, according to the TV news, David Stockman says it's got to go. He's probably right: it must be cheaper to send a Senator on a junket to outer space than a high-school girl for a train ride to Philadelphia. Whoever asserts otherwise will be suspected of high irony. 


\section{Best Time Of Year}

7 he last week of May is surely the best time of year. All of nature is in 1 bloom. Travelers on Palmer Avenue are treated to the beautiful display of azaleas of Mr. Tavares and Mr. Marshall-a treat to the eye. The old maples are in full leaf. The copper leaves of the great old beeches that Henry Fay planted on his land in Woods Hole have come forth again.

Other trees still bide their time. I am thinking of those beautiful blueflowering trees, one of which graces the little parking space on Miles Pond where Sam Cahoon's ice house used to stand and another on the right of the driveway leading to the Grain Mill. Alfred Redfield once told me their name, but it has slipped my mind, and I wish someone would tell me again.

The last frost, we hope, has passed. Gardeners wager that they can safely put out their tomatoes and peppers. Peas are almost knee-high, and so are the uncut spears of asparagus. The beach plums are whitened with their little five-petaled flowerlets, and the blueberry bushes are thick with greenish-white waxen balls.

It is a delicious time of year, a respite before the serious business of summer begins, and our annual visitors arrive from across the bridges. For a short precious time we have the Cape to ourselves.

The long Memorial Day weekend is upon us. Some irreverent legislators have made it into a Monday for the convenience of vacationers, perfect for a weekend binge. But somehow I think Memorial Day is too solemn a day to be pushed about $\longrightarrow$ oh yes it is. 


\section{Secrets}

W hen one considers how open and hospitable the scientific institutions in Woods Hole are to the public today, it is hard to remember the days during and shortly after the war when they were protected by guards; we all had security clearances, and papers were stamped with the words Restricted, Confidential and Secret, and locked away at night in safes.

However, Falmouth is a small town, and despite the efforts of Jeff Allen, and T.S.P. (Teaspoon) Griffin, who had responsibility for maintaining the security blanket, information about our activities had an unnerving way of spreading around.

The air of secrecy surrounded the Institution until after the Bikini atom bomb tests, in which the Oceanographic took an important part. Allyn Vine took on the job of designing some recording pressure gauges to monitor the height of the man-made tidal wave that was expected to radiate from the center of the explosion in the atoll.

My friend Otis Hunt and I were working for Allyn and helped him build them. They had, as I recall, a circular sheet of smoked paper rotated by a clockwork and a Bourdon pressure gauge with an arm bearing a needle that scratched a trace in the smoke. Both Otie and I found our intellects stretched beyond the limit in trying to comprehend the mechanical theory of the Bourdon tube - a veritable marvel of solid geometry-but fortunately we didn't need to understand it to put the gauges together.

They were enclosed in heavy cases made from, I believe, 12-inch Walworth pipe caps and bolted together with old-fashioned rubber gaskets. Those were the days before the marvellous O-ring pressure seal. Otie and I suffered numerous cold February days on the Asterias testing them out by trying to record the tides at Sheep Pen Harbor.

Before he left for Bikini, Allyn suggested in passing that we could refer them by the code name "Turtles"-which we soon forgot. Weeks later the telephone rang in the office. One of us picked it up. It was the Western Union operator with a cable from Allyn: "The turtles worked O.K." Momentarily taken aback, I asked her, "Did you say turtles?" "Yes," she replied, "it says turtles, but it means pressure gauges." It is difficult to keep secrets in a small town. 


\section{The Blue Tree}

7 he international language of science, in the days of Newton and 1 Descartes, used to be Latin. For a while, early in this century, it seemed it might become German, but today it is incontestably English.

An international meeting of scientists in Tokyo, for example, may offer simultaneous translation, but all of those present will be listening to the English version, except for a few Canadian bureaucrats with their earphones on trying to learn French. About the only vestige of classical usage that survives is the nomenclature still in use in some of the natural sciences, such as botany, and the Latinized surnames of some Scandinavian scientists. Linnaeus comes to mind.

Two years ago I visited his tomb in the cathedral of the little town of Uppsala, next to the university where he served and practiced medicine until his death in 1778 . The tomb is rather severe, a block of polished stark red stone, inscribed Carl von Linne. On the far side of the tiny river that flows through the center of town is his house and the site of his experimental gardens. His collections and library are not there-they were sold by his widow to the English president of the London Linnean Society. Linnaeus will always be remembered as the founder of the modern system of classifying the kingdoms of living things.

Several readers communicated to me the name of that lovely blue-violet tree by the side of the ice-house pond and at the entrance to the Grain Mill. A small grove is also on the Fenno estate. I am told that the scent is similar to that of European violets.

It is a genus of the scrophulariaceous trees, species Paulownia tomentosa, named after the Russian princess Paulovna, daughter of the mad Tsar Paul I, whose reign terminated only when he was murdered in his bedroom in 1801 .

My garden encyclopedia says it is root-hardy even as far north as Montreal, and that when killed back by frost, new shoots grow vigorously from the stump. That certainly seems to be the case of the Fenno trees. They are also said to stand up well to the salt air-perhaps that is why some of the older gardeners planted them here and there upon the Cape. 


\section{Dragon's Blood}

$\mathrm{H}$ ow many now remember that large glass-stoppered jar of colored water that used to hang in every drugstore window- the very trademark of the apothecary? Things have changed so much-even the soda fountains are gone. Leafing through my 1877 edition of the Dispensatory of the United States I was struck by all the vanished names: Baume Tranquille, Pilula Colocynthidis Composita, Tinctura Rhei Aromatica and Linimentum Terebinthinae (turpentine liniment, in case you didn't know, and you weren't supposed to). Even the inorganic chemicals had Latin names: Hydrargyri Oxidum Rubrum, Plumbi Carbonas. Today we use a modern language, but the symbols in the chemical formulas still mirror the ancient alchemical nomenclature.

In 1947 I determined to manufacture my own zinc cuts for my newly acquired printing press. During the process of etching, a resinous substance should be dusted on the plate to prevent the acid from undercutting the unetched portions. This resin, from a small palm that grows in the Molucca Islands, goes by the curious name, "dragon's blood" (Sanguis Draconis). It used to be sold as a fine scarlet powder. I hesitated for weeks before entering a drugstore to ask for "powdered dragon's blood."

Do you remember the white frame building next to the bridge in Woods Hole, opposite the barber shop with Al Blanchard and old Sherm Eldredge presiding over the chairs? It was where the Redfield Building parking lot now is, and it used to belong to Mr. Daley until Ed Jaskun purchased it in 1948. It seemed to me that Mr. Daley might be old enough not to be shocked by a request for powdered dragon's blood, so I sauntered in and casually asked for some. His face lit up with a smile as he exclaimed, "Why, nobody has asked me for it for years!" 


\section{The Dollar}

renched in sweat and mosquito repellent, I climbed out of my monster lawn mower to find Dr. Hashelew sprawled in a chair in the shade beside my tool shed. He was obviously in need of an audience for a new idea and had selected me to try it out on.

"As you know," he said, "I am seldom taken in by a con man, but years ago, when the French government had just revalued the franc at the rate of one new franc to a hundred old francs, I flew into Orly to deliver a lecture at a geographical congress on my interpretation of the inscriptions on Dighton Rock.

"I was so confused by lack of sleep, the hubbub around the moneychanging booth, by the taxi driver who pretended not to speak English, that when he quoted the fare in old francs he managed to con me out of almost all my pocket money.

"By the process of association of ideas, it occurred to me that the President could propose a revaluation of the dollar instead of his tax reform. If there is anything that disturbs us oldsters, it is that today a fiftydollar bill bears the same sense of substance that a five-dollar bill used to. There is something unsettling about it.

"So why not propose the issue of new dollars, at the rate of one new dollar for 10 old dollars? The price of everything would go down; gold would resume its old thirty-five dollars per ounce and a visit to the gas station would not even break a five-dollar bill.

"Revaluation would be largely cosmetic, of course, but so is what most of what politicians propose. We would gain as a nation an aura of financial stability. It would reduce the figures of our national debt.

"From an international point of view it would augment our image more than going to the metric system. Imagine the repercussion when the exchange rate read eight pounds sterling per U.S. dollar. And right in line with the President's goal of tax reform it would automatically, for all of us, lower our tax brackets.

"And just to show you what a good friend I am, I'll invite you to join me in getting a hackney license so we can meet international arrivals at Logan Airport." 


\section{Pathways}

Tnstead of laying out paved pathways on abstract principles, architects of new institutional campuses sometimes sod them entirely with grass and wait until rough pathways develop spontaneously by most frequent use, before paving them permanently. It is a wise way of determining the otherwise incalculable, and tends to forestall widespread future walking on the grass.

If the heavy traffic reported on Ter Heun Drive is regarded in this light, we could infer that it has proved a most convenient direct route to Sippewissett. The public finds it useful even though it is not yet completed and despite a short unpaved stretch. Even though the owner of Clowes Drive has decided to bar its use to the public (so that we can no longer drive direct through to Sippewissett Road), Ter Heun Drive remains remarkably popular.

The land along Ter Heun Drive was acquired by the town at the time that the hospital was built to satisfy a government regulation requiring two access roads. Some time later a section was bulldozed at the initiative of Mr. Burnham to connect it with his development, Knollwood. Now it extends up to the Clowes bypass at the "Highlands." With the blockage of Clowes Drive, cars and trucks now stream through Myrick, Highcrest and Burnham roads. Should the short remaining portion of the original layout of Ter Heun Drive be completed straight through, this backup, overflow and congestion might be relieved.

Some residents of Sippewissett resist the completion of Ter Heun Drive on the assumption that it will bring more traffic past their houses. They overlook the fact that the flow of traffic is two-way and that it will also draw traffic off the road. There has indeed been an increase in the traffic on Sippewissett Road, but one suspects that this is a result mostly of the fact that owners of land along Sippewissett Road have built so many more houses. Each new house means two more cars on the road.

The distress caused by debates over extending Ter Heun Drive is symptomatic of the inner conflict in our minds between trying to preserve the privacy and amenities of a less populous past, and, at the same time, to profit as much as possible from the increase of the population. 


\section{The Captain's Legacy}

Tf we don't have many good travel books about heaven, it is because very 1 few of us have been there. You can get a distant view if you drive up to Nobska some quiet morning and gaze out southwestward along the hills of the Elizabeth Islands. There is a stretch of land-as far as you can seepreserved in the primeval state in which it was acquired by the Forbes family over a century and a half ago.

It is the closest approach to a garden of Eden here in the East, and the reason is that the rest of us have not had the liberty to build houses, roads and junk food plazas or to invade it with our automobiles and noise.

Even the National Park Service couldn't do a better job of keeping it pristine; they would build lodges and ferry tourists across Woods Hole to trample the pathways down hard and litter it with candy wrappers and plastic cups. And so it is far better that we can view it only from afar, for, in truth, we are the despoilers. Naushon is a natural heritage, and it is in good hands.

When a few more decades bring us all to recognize rapid land development for the evil that it is, we should not infer that the developers themselves are evil men. They are just poor mortals like us with perhaps a more developed instinct for what the TV commercials call "making a killing at real estate." Many of the old whalers were devout Quakers, good men and true. Yet today we perceive the hunting of whales to be an evil.

Once upon a time I knew a professor of mathematics at MIT who was a descendant of the incorruptible Commissioner Lin. In the early part of the last century, British and American shipping merchants had established a flourishing opium trade in China. Lin was appointed by the emperor to stamp it out.

There are many pages in Basil Lubbock's The Opium Clippers devoted to the career of Robert Bennet Forbes, certainly one of the most outstanding and able clipper captains that America can boast of. He was also responsible for almost every American-built clipper in Chinese waters.

In 1828, at the age of 24, he commanded the Bashaw, and in company with Captain Smith of the Leander carried 1,000 chests of Turkish opium to Perkins and Company at Canton, at a profit of about 12 million dollars in today's money.

As the sluggish conscience of the world began to grow aware of the untold misery this trade inflicted on the Chinese people, and as Commissioner Lin's efforts led to the Opium War, what had at first seemed to be just "good business" was eventually perceived as a social evil.

But it is not going too far to assert that those old skippers could still be considered good men. And certainly the fortune that Captain Forbes founded has provided the means to keep, love and cherish one of the last great natural reservations free from land development. 


\section{The Silent Cyclists}

T ncle Zeb paid me his weekly visit yesterday. He doesn't have to walk far, just across the street. And he has to do that to reach his mailbox anyway. "I think I'll get mailbox insurance," he announced. "I didn't notice that anybody had knocked yours around," I replied.

"Oh it's not the mailbox I'm thinking of, it's me. Every time I go across the road something comes zipping by, and I have to be on the alert not to get knocked down for the sake of some bills and junk mail."

"There certainly are a lot of cars these days," I said consolingly. "It's not the cars I'm worried about," he said. "They make so much noise that I always hear them coming. Maybe a Rolls Royce could creep up on me. Then I'd have somebody rich to sue. I think that I'd find a sympathetic jury - it might even be worth it.

"What bothers me is the prospect of being struck down by one of those silent bicycles that come swooping round the bend. You don't hear them coming, and they can be on you in a flash. In one instant you'll be tangled, with a thud, in a mass of twisted wheels, broken spokes and bleeding bicyclist.

"There is a hierarchy in the community of those who use the road. Truckers are at the top because they are bigger. Then come the automobilists, who expect all lower breeds to yield the right of way. The bicyclist, who suffers from this discrimination, takes it out on the poor pedestrian, who is at the bottom of the pecking order-except for the skunks and turtles.

"I do not want to contest the pecking order, even the low place that I occupy on it. I'll yield the right of way to anyone on wheels, to the oft harried bicyclist or even someone with a wheelbarrow. But why don't bicycles carry bells anymore - to warn us to scurry out of their way?" 


\section{The Viper's Jaws}

7 he narrators of those sentimental nature documentaries are fond of 1 reassuring us that the field mouse in the viper's jaws feels no painthat it is in a state of shock. But I have seen men die. The poet W.B. Yeats, in his poignant "Sailing to Byzantium," portrays the death of old men more truly: how the soul, sick with desire and fastened to a dying animal, knows not what it is.

The operation is over. The nurses tend you with gentle hands. The surgeon describes what he has found, but his moist, compassionate eyes tell you that there are limits to his skill. Your old friend, the family physician, reassures you that you will not suffer pain and sadly averts his face. Bewildered family members gingerly enter the sterile room, awkwardly attempt to express their love and hastily depart, with sorrow and relief, to the sun and fresh air in the parking lot. And you are left to face the unknown terror of the coming night alone.

As Mark Twain grew older, and others in his generation began to pass away, he asserted that though others died, perhaps in his case there might be an exception. An active mind stays young, though chained to a dying animal body. We have been given the precious gift of life, a chance to contemplate a surpassingly beautiful universe, minds in which to cultivate some measure of wisdom and the companionship of other creatures no less mortal than we.

If in the midst of an often crass and strident society, we have learned to love this world, if we have managed to control our avarice and learned to give rather than to take, and above all to give ourselves to fellow human beings, then we may discover how, with grace, to give ourselves to death. 


\section{How Do You Spell It?}

Tn the years before a federal court decided Ma Bell's children could 1 make it on their own and ordered the old lady out of the house, no one would have dreamed of tinkering with the phone. Now every five-and-tendollar store offers a variety of equipment for the householder to install himself. It is alleged that recently an inmate of one of the Woods Hole institutions got so impatient waiting for a phone to be installed in his laboratory that he broke into the junction box down the hall and made such a mess monkeying around in it that the phone company had to be called in to straighten it out again.

For many years the administrative department of the Oceanographic was so small that it was all housed in one building, the White House, framed and finished by our carpenter Stan Eldredge himself. It used to stand back of Bigelow where the greensward now lies. In this one place, John Churchill and Ginny Peckham ran the marine department; Jeff Allen, personnel; Bill Schroeder and Mary Ortolani, purchasing and accounting.

The telephone exchange on the second floor was presided over by Rosemary Gallagher. One of the wonderful things about Rosemary was that she knew where everybody was. If you asked for Henry Stommel a little after ten she'd put you through to Fritz Fuglister's office, because she knew they'd be having coffee together.

Rosemary was, I think, overworked. In addition to typing she was expected to keep accounts on all toll calls, and when she asked for a parttime high school girl to collate toll charges with their proper accounts it was decided to install a modern automatic dialing system instead. The new system was moved into the Smith building. Rosemary did not move with it. There were two new operators. When you wanted to make an inside call you had to look the number up yourself. That's the way with automatic systems.

Our old director Columbus Iselin had retired for the last time. But he still came to work most days. He was a father figure to us all. Some months after the new system was installed I called in from outside and asked one of the new operators to put me through to Mr. Iselin. She hesitated and then asked: "How do you spell it?" 


\section{Nomans Land}

$\mathbf{F}$ or many a homebound seaman or fisherman the first tangible evidence F of approaching the coast is passing the Nomans buoy. The island of Nomans Land itself, seven miles south of Gay Head, looms on the starboard bow, solitary, dark, mysterious. In the last century it served as home for a few fishing folk, some farmers, and for awhile even an unsuccessful sport club. Then, in 1913, the whole island was purchased by Joshua Crane, a Boston businessman. A summer house and airstrip were constructed, the old farm put in working order, and, one hopes, for awhile served as a marvellous retreat for the owner from the world of business. There is a book, entitled, as I remember, Isle of Romance, written in rather lyrical prose by Annie Wood, a relative of one of the Cranes' year-round caretakers in the 20's. It used to be offered on sale at the New Bedford Whaling Museum-my copy was often loaned and is now long lost. You can probably find a copy in the library.

For many years now, Nomans Land has been a restricted military area, reserved for aerial bombing exercises. The public is expected to keep off, but, of course, teenagers land from time to time from their Boston Whalers, and walk the lonely beaches, or visit the freshwater pond there. It is said that they do so at some risk, because there may be live unexploded bombs strewn about the cratered landscape. It is true nomans land.

Should it someday come on the market, some enterprising soul might conceive of establishing a holiday resort there, complete with swimming pools, discotheques, tourist cottages and all the accoutrements of a Club Cap Codiennee. It ought to be possible to clear the fields with a little care and a flock of sheep. But there must be many a man whose life has been spent here on the neighboring mainland and islands who hope that time will never come. Better the craters, the emptiness, and the brooding silence of this bomb-blasted island, looming at the entrance to the Sound.

When I was $25 \mathrm{I}$ became consumed with a romantic impractical desire to possess Nomans Land. I had sailed along the coast of Maine where truly beautiful islets were being offered at prices averaging $\$ 1,000$, but they were far away. Somehow I discovered that the owner was living in Barnstable, and I was rash enough to write him requesting an asking price.

He courteously replied that he was willing to sell it. With a sharp feeling of shame for having been so forward as to trouble him over something far beyond my means, I wrote to him an apology for my impulsive act. There was no likelihood that I could have lived on the island, and it would have required my raising 12 times my annual salary. The asking price was $\$ 35,000$. 


\section{Dr. Hashelew's Plan}

$\mathrm{O}$ $\mathrm{n}$ the first of July I drove Dr. Hashelew to the airport for his annual vacation in Florida. He prefers places without crowds, and low rents. Some of his acquaintances say, when he leaves the Cape for Florida, that it is an improvement to both places.

He was in something of a black mood because his fraternal order had not acted upon his suggestion that they donate a public lavatory for the Village Green. "It really is a necessity that has been recognized by other towns-just look at Lexington's Minuteman Memorial Rest Room."

His brain was whizzing with plans for after Labor Day, when he plans to return to the Cape. He turned to me with a look of cunning on his face and said: "On an island under the bridge to Asnières, north of Paris, there is a marvellous animal cemetery. My wife and I happened to visit it on All Saints' Day, when French families picnic beside their pets' memorials, bring flowers and other pets for a visit, wash and polish the stones. At the entrance gate there is a grand statue of the hero dog Barry, known to every French schoolboy as the rescuer of countless snowbound travelers in an Alpine pass.

"When Barry was full of years, his last rescue went awry. As he approached the fallen freezing traveler, his cask of brandy was not seen, and being mistaken for a wolf he was shot. Wounded, he crept back to the monastery, and the kindly monks, retracing his bloody footprints in the snow, rescued the man who shot him.

"It occurs to me to turn my six acres into an animal cemetery-another facility much needed around here. Allowing one acre for walks and drives, there will be 200,000 square feet available for burial plots. A cat only needs at most one square foot, and at $\$ 200$ a plot that sums up to $\$ 40 \mathrm{mil}-$ lion dollars, only part of which will go into a trust fund to provide for perpetual care. I don't anticipate any trouble with the planning board, do you? One ought to pick a time when they are all in a good mood. Perhaps I ought to buy them each a swivel chair." 


\section{King Of The Islands}

$\mathrm{O}$ ne of the entrancing dreams that floated about the Rectory in Woods Hole in the middle 40's was that of cruising around the world. A casual visitor on a Saturday morning might find Dave Barnes, Charlie Blevins, Bob Price, Dave Baldwin and Billy Butcher earnestly debating what they would have for breakfast on the 285 th day of the voyage they hoped to make. Wistful, unfulfilled dreams.

This summer those who read Capt. Joshua Slocum's classic Sailing Alone Around The World for the first time will doubtlessly harbor similar dreams. They may wonder what happened to the hereditary governors of the CocosKeeling Islands, in the Indian Ocean, where Capt. Slocum tarried for five idyllic weeks in July and August 1897.

The islands were first permanently settled in 1827 by Capt. John Clunies Ross and his family, and some Malays whom he recruited for labor on his copra plantation. By the time of Slocum's visit, Ross's grandson George was the ruler. Once, when a London tailor who was fitting him remarked: "Sir, you look like a king," George Ross loftily replied: "I am a king."

The islands were benevolently governed, after the fashion of the times. A British man-of-war would occasionally visit them to assert a loose form of dependency. The Rosses found these visits useful as a way of deporting troublesome castaways, or adjudicating serious crimes. In 1901, shortly after Slocum's visit, Ross leased 40 acres for a cable relay station linking Great Britain to Australia and Singapore. During the First World War the German raider Emden destroyed the cable station, but little else disturbed the tranquility of the island kingdom.

In 1942 its lagoon served as refuge to retreating Catalinas of the Dutch Air Force. The year 1944 brought the first airstrip. By 1951 Qantas planes were refuelling on Cocos-Keeling Islands on their run between Australia and South Africa, but with the advent of planes of longer range the airport was less visited. Even the rivalry between the U.S.A. and the U.S.S.R. in the Indian Ocean during the 60 's did not disturb the private fiefdom, its 350,000 palm trees, its 493 Malays, or the 5 th hereditary governor who owned the whole place, made the laws and issued his own coinage.

Then, on Aug. 30, 1972, an Australian tabloid headlined an expose of "slavery" in an Australian territory. Surrounding East Asian countries echoed the cry. The Australian government, under siege by the Labor opposition, was obliged to act. An official investigation revealed that the island was actually well governed, and that, if empowered to vote, the islanders would freely elect Ross to continue as their leader. But appearances must be preserved and a principle involved. Ross was persuaded to abdicate. The Australian government purchased the entire estate in 1978, except for 12 acres, upon which the man who was once king still (as of 1983) lived. It took a long time for the 20 th century to catch up with Capt. Slocum's favorite tropic island. 


\section{Verbal Darts}

$\mathrm{T}$ he shafts of Cupid's arrows are said to bind the hearts of lovers. We, on the other hand, have invented verbal darts. The little boy, about to execute a difficult feat of mumblety-peg for the edification of his playmates, is mortified by his younger sister when she runs up to call out: "Jimmy come home, Mother wants you." With the right inflection that simple sentence can inflict a sharp sting.

Perhaps you have just come down from Worcester, settled your family and wandered down to the boat yard to determine whether they have put your boat in the water yet. You encounter Uncle Zeb painting his skiff. He looks up with a grin and asks, "Down for the summer?" Pronounced with the proper Yankee nasal twang, with an upward lift at the end, it conveys a trace of sarcasm that draws an unmistakable line between the visitor and the native. You feel hurt a little by the barb.

The time was once that if we had to pass through the corridor of tourist traps outside of Buzzards Bay, or go shopping in the commercial penumbra surrounding Hyannis, we'd likely comment to a friend: "Terrible what's happening to Hyannis."

I had to go down Cape the other day to get some hydraulic fluid for my tractor. They had it, all right, but in large drums, and I only wanted a few quarts. As I waited for the boy to find an empty can, I fell into desultory conversation with the parts clerk. I've known him for years, and he knows where I live.

I commented on the astonishing proliferation of roadside business establishments around him and the seething summer traffic. Writing something on the invoice and without looking up, he replied: "Terrible what's happening in Falmouth." 


\section{Close Encounter}

$\mathrm{W}$ hen Halley's Comet visits the sun again this coming spring, it will herald the 300th anniversary of Newton's presentation of Principia to the Royal Society in April 1686. All during the summer of 1685 Newton labored upon the final draft, and the world of science was never the same again.

Halley became the Astronomer Royal and began to apply the theory of universal gravitation to comets. Assuming that the orbits of comets are parabolas (a geometrically simpler form than extremely elongated ellipses), Halley calculated the elements of some 24 comets observed back to 1337 . He noticed that the elements of the comets of 1531,1607 and 1682 were much alike and speculated that they might all be appearances of the same celestial body. He predicted that it would appear again in 17581759.

The reason for the indefiniteness of his predicted date of reappearance was that there was a 15-month discrepancy between the periods of historical appearances. The interval between 1531 and 1607 was 76 years and 62 days; that between 1607 and 1682 was 74 years and 323 days. He attributed this difference to the derangement of the comet's orbit by its encounter with Jupiter. However, the means of calculation of this derangement did not exist in Halley's time. He died in 1742, leaving it to the French mathematician Clairaut to attempt a more precise prediction. Clairaut managed to present it to the French Academy just one month before Halley's comet was seen again. His error was 22 days.

The advent of computers has made calculations of the motions of comets much easier than they were in Halley's time. It might make a good science project for some Cape Cod high school student to demonstrate with a program on the screen of his personal computer just how a massive planet might be expected to affect the orbit of a highly eccentric comet during a close encounter. As a starter, one could begin with both orbits in the same plane.

So I'm offering a prize of $\$ 250$ for the most interesting entry by a high school student, or younger, to be judged by two of my scientific friends. We will be looking for some physical understanding of the phenomenon and the discovery of some good questions. An actual prediction of Halley's Comet itself would be more intricate and is not expected.

Entries on a floppy disk, with an explanatory essay, should be at The Enterprise office by Thanksgiving. Entrants should put their names on both disk and essay. 


\section{"Starbuck" Offers Prize: \\ A Computer Challenge For Young Students Of Physics}

$\mathrm{O}$ n the editorial page today, in his usual space, we have our columnist, "Starbuck," offering a prize of $\$ 250$ to the high school student, or even a younger than high school student, who submits the most interesting solution to a problem in physics, using a home computer.

The project: to demonstrate with a program on the screen just how a massive planet might be expected to affect the orbit of a highly eccentric comet during a close encounter.

Starbuck's inspiration was the impending return of Halley's comet. In an interview, Starbuck enlarged upon it.

Q) Why are you offering the prize?

A) It seemed to me to be an appropriate way of celebrating the anniversary of two great achievements: the invention of particle mechanics by Newton, and the application of his ideas by Halley to a bold prediction of the reappearance of the comet that will visit us again next spring. Also, I wanted to encourage that small fraction of high school students who have an interest in physics to teach themselves something about celestial mechanics in Newton's simple precise way.

Q) Are you asking them to do something too difficult?

A) Well, I worried a bit about that, and talked with some people who know something about our annual science fairs, and they said that it seemed like a fair exercise that some of the students could carry out. It ought to teach them something, build their confidence and interest.

Q) Suppose that I were a good physics student, knew some trigonometry, enough to resolve forces. Suppose I understood the formulation of Newton's Laws and how to write simple programs on a computer with a display monitor. How would I get started on the comet problem?

A) It seems to me that the first thing to do is to do just what Newton did, but, avoiding the much more cumbersome primitive mathematical and computational methods of his day, I'd put a sun in the middle of my screen. Then I'd put a planet like Jupiter at some initial radius from the sun. I'd write a little program that makes it move according to the inverse square law of attraction. Then I'd give it a tangential velocity to start with, and study the orbit that results. I'd try various values for the initial tangen- 
tial velocity to observe the shape of orbit. I'd try to verify that they are always conics with the sun at a focus. I'd try to find the starting velocity that makes the orbit a circle. Then I'd try to devise a display program that would verify Kepler's laws just as Newton did.

Q) What you mean is that you'd start with a simpler problem than the comet one?

A) That's right. First I'd try to get Jupiter going around the sun in a circle, and understand this.

Q) It was all done a long time ago. Is it still important?

A) I would say categorically that if you can't work out this one planet problem one way or another, you don't understand classical physics.

\section{Q) The comet problem is much harder, isn't it?}

A) Not really. Not with a computer. You simply assume that Jupiter just moves exactly as it did without the comet. The comet has too small a mass to affect Jupiter. Then you let the comet feel the gravitational attraction of both the sun and Jupiter at every moment. Jupiter has a much smaller mass than the sun, so the comet will mostly feel the attraction of the sun. So it will mostly follow a conic too, one of its own. But it does get nudged about by the smaller mass-attraction of Jupiter. The computer can handle that beautifully. So now there is a new system to study. It used to be called the restricted three-body problem and was regarded with awe.

\section{Q) Have you tried it yourself?}

A) Yes, I made up a little comet program. I made Jupiter $1 \%$ of the mass of the sun to get a stronger effect than in the real solar system. Then I arranged the comet to have two orbits-one that feels Jupiter's attraction and one that doesn't-as a basis of comparison. A color monitor helps to keep them separate and identifiable.

\section{Q) Will it take a lot of time?}

A) Well, if you like science, time doesn't matter. It will be fun. Actually to write the comet program won't take more than a few hours of fooling around. But to use it to study the cometary problem, and to derive some results and understanding of what the perturbation of Jupiter does to an otherwise elliptical cometary orbit will provide food for thought much much longer. Good luck!

Q) Why $\$ 250$ for the prize?

A) It's not much by today's standards, I suppose. But it's more than Halley had to dig into his purse for to get Newton's book published. In the past three centuries the value of money and the scientific interest of cometary orbits have both depreciated. 


\section{First On The Bonins}

Tn early 1830 sailor Nathaniel Savory of Bradford, Massachusetts, was on 1 the beach in Honolulu, waiting for his hand to heal. He had lost a finger while firing a salute.

News came in of the just-discovered uninhabited Bonin Islands, stretching 500 miles southward from Tokyo. The southernmost had been discovered by a Nantucket whaling captain and was named Coffin Island. Today we know it as Iwo Jima. Capt. Beechey of H.M.S. Blossom charted the main group. He named them after British dignitaries.

With two fellow drifters, English subjects, a Genoese, a Dane and a group of Hawaiians of both sexes, Savory landed on Peel's Island (now Chichijima) on June 26, 1830. They cleared land, planted gardens and engaged in trade with passing whalers. Savory's diary was lost to a seismic wave, but a sea chest with his correspondence for the following 44 years survives. The majority of the Europeans being British and the island having been claimed by Beechey for England, they settled under the authority of an affidavit from the British consul at Honolulu.

Over the next 44 years, until he died in his 80th year, it was Savory's oral authority that held the colony together. Some of the others drifted away to the Marianas; one attempted to murder him. Savory's voluminous correspondence with New England merchants is what maintained the tiny economy and trade. Had he been a British subject, Savory would have been made governor.

When Commodore Perry dropped in on Savory in 1853, during his celebrated "opening of Japan," he purchased land for a coaling station and enrolled Savory as an agent of the U.S. Navy. Even more high-handedly, Perry appointed Savory chief magistrate. This infringement of British sovereignty might have passed unnoticed had it not been for the eagle-eye of the old British consul, then retired in Scotland. Perry had a chilly reception when he steamed into Hong Kong.

Savory died in 1874. In 1875 a Japanese delegation arrived, assembled the motley colony, distributed free blankets and cakes and announced that henceforth the settlers were under the protection of the emperor. The British consul in Japan arrived two days too late. He spied an American flag flying over the house of Savory's widow. It was to be 70 years before an American flag flew there again.

One of Savory's earliest companions was a native of Brava, Joachim Gonzales. It was his grandson who as pastor held the tiny church together under Japanese rule up through World War I. Further immigration of Europeans was banned, but the Rev. Lionel Cholmondeley of St. Andrew's Mission was permitted to visit.

According to the present bishop of the diocese of Tokyo, the Rev. John J. Yamada, it was the remnant of this tiny Anglican communion that was first allowed to return to Chichijima by the Occupation Authority after the last war. 
On August 7, 1985, the following editorial appeared in The Enterprise:

\section{Starbuck's Challenge}

$\mathrm{W}_{\mathrm{p}}^{\mathrm{e}}$

e must now identify our columnist, Starbuck, who has offered a prize of $\$ 250$ to the student of high school age or younger who can come up with the best home computer program postulating the gravitational results of a close encounter between a planet and a comet. A person cannot be allowed to flash that amount of money without being identified. He is Henry M. Stommel, an old friend of many Enterprise readers, and perhaps most had already penetrated the nom de plume that, in fact, goes back 30 years.

That Mr. Stommel created this challenge, drafted the rules and will be responsible for the judging is worth a suitcase full of credentials. It gives the contest all the academic authority needed and more. It is also assurance that the contest will be fun. In a long career of scientific accomplishment, Mr. Stommel has found fun in just about everything that he has done and has mellowed accomplishment with good humor. Nobody should be frightened out of the contest thinking it too weighty and serious.

We know that within the families of a great many Enterprise readers in our Upper Cape towns are young people that are eagerly adapting to the computer age, young people with inquisitive minds that are drawn to the wonderful world of classical physics. If Starbuck's challenge could be successfully taken up anywhere, it can be successfully taken up here. We are confident of that.

To sweeten the pot, as they say in another sort of competition, The Enterprise is now adding $\$ 250$ to Starbuck's $\$ 250$, making the prize $\$ 500$.

Any inquiries may be addressed to "Starbuck Contest," care of The Enterprise; Box 647, Falmouth, 02541. And further details will be published.

Note: A few years later, Hank Stommel assembled 23 of the Starbuck essays and sent them to friends and colleagues with a note that said, in part:

“...a pseudonym serves a more important purpose than protection from malice. The letter writer tries to think as an alter ego and becomes another person. Open expression of deep feelings is easier behind the veil of the confessional.

"In August 1985 the Editor revealed Starbuck's identity. The stream of letters faltered, then flickered out." 


\section{Remembering The Woods Hole Follies}

$\mathrm{t} 8 \mathrm{o}^{\prime}$ 'clock on the nights of Feb. 19, 1945, and March 8, 1946, the
floorboards of the old Woods Hole Community Center groaned under an evening of entertainment that was known as the Woods Hole Follies. It was a time of earnest involvement of the Oceanographic in war research: submarine detection, design of depth charges and development of antifouling paints for the Navy. The Follies provided a little comic relief. The producer was Mary Cobb.

My dim memories of these happy occasions were refreshed recently when an old packrat friend, Bull Dinkle (a pseudonym, to shield his identity), unearthed the programs. Long forgotten pictures began to reform in my mind's eye.

The programs were a mixture of the serious and ludicrous. Personalities were on the line. Professor Clarke, of Harvard, did a piece called "How to Make a Wave." Alfred Redfield starred in a skit titled "The Lecherous Gentleman from Esquire," with the assistance of Madeline Broadbent, redhead; Barbara Brooks, blonde; and Kay Wingate, brunette.

Bill Shultz did his famous shuffle. The foremen of the shops, Chuck Bodman and Stan Eldredge, armed with ripsaws, claw hammers and a crowbar, and with Ginny Peckham as nurse, performed a public surgical operation on stage, extracting long strings of sausages and baloney from the discreetly sheeted patient. Gloria Clark and Henry Cattley did a polka, and an otherwise very shy and reserved young lady, who was aptly billed as "the startled fawn," performed a moving pantomime of getting undressed and taking a shower.

There was more serious entertainment as well. Jean Keen and Pat Brown played a xylorimba and piano duet. Eileen Scharff sang "My Hero" from "The Chocolate Soldier."

The Chamber Music Society of Upper Little Harbor Road treated us to an especially ambitious piece. Fritz and Cecelia Fuglister were violinists; Don Wilson played the flute; Ruth von Arx, the viola; Mary Lou Smith, the cello; Paul Smith, the soprano recorder; and Jack Decius, the tenor recorder.

I don't remember just what it was that they played, but it was sedate, well done and very long. Time moved slowly and seemed to come to a stop. The audience grew restless. It was longing for some of the rougher stuff, scheduled to follow on the program, but remained appreciative and polite.

Finally, our musicians came to the end. The audience, in its relief, applauded wildly and loudly. Mistaking the uproar as a demand for an encore, the ensemble resumed their seats and played the entire piece over again. 


\section{Kingdom Of Humanity}

hould some reader determine to emulate Capt. Slocum and ask me to identify a tropical island ruled by a European king to visit, I am afraid I could not help him. The last of the long line of White Rajahs of Sarawak abdicated in 1946. There are some good biographies of the Rajahs Brooke: perhaps the best is that of Lord Runciman. A lesser king was John Gawsworth, who claimed sovereignty over Redonda in the Antilles, but died in 1970. The ranks are thin.

There is, of course, the Kingdom of Humanity, sometimes referred to as the Republic of Morac-Songhrati-Meads. But I don't recommend that you go there. It is an archipelago of tiny islets in an area long denoted on nautical charts as the Dangerous Ground, within the South China Sea.

Early navigators avoided it. France claimed it in the 1930's. In 1938 Japan occupied it and built a submarine base on Itu Aba, but relinquished the islands after the war. Today Vietnam, Taiwan and the Philippines maintain garrisons on them and search for oil. Red China has no soldiers there, but claims the whole shebang.

An American, Morton F. Meads, claims to be the hereditary king. Marwyn Samuels, in his recent book, Contest for the China Sea, describes an affidavit submitted by Meads's subjects to the United Nations and the U.S. embassy in Manila in 1972. Great-grandfather Capt. James Meads is supposed to have discovered the islands in 1870-but this can hardly be true inasmuch as they were surveyed years before by Capt. Tizard of H.M.S. Rattlesnake.

Allegedly the islands were settled in 1914 by Americans, who resumed their residence in 1946 after the Japanese left, but there seems to be no trace of their settlement. In 1972 all six elderly pioneers of 1914 were drowned when their ketch, E Pluribus Unum, sank off Mindoro during a typhoon, leaving only the young chief of state. And when the United States withdrew from Indochina, the future prospects for the dynasty must have seemed dim indeed.

Samuels points out that the affidavit is vague or silent about many details. He seems doubtful of the facts as stated and implies that it may be an invention. Out of curiosity two years ago I wrote to the king at his embassy in Manila for clarification. I had to write via an intermediary, whose replies were guarded and suspicious of my motives. His letters were not typed on embossed royal stationery-but on what may have been a generic brand of paper towel. My correspondent wanted to know whether I worked for the state department or was an agent of an elusive outfit called the Society of Oceanic Microstates, purported to be based in Saint Louis. I couldn't locate them either. 


\section{Groundwater Simulator}

Dilots of large airplanes are accustomed to training in flight simulators, 1 controlled by computers. It is a safe way of learning by mistakes without endangering live passengers. Engineers designing complex systems use simulations too. They learn what properties of their constructs need to be known in order that the systems may run properly. Improvements in the simulators lead to better understanding and real systems that run better.

Some of our local talented high school science students may well be considering entering the profession of groundwater engineering. It will doubtlessly be a subject of local interest in the future. The level of public discourse will improve as the understanding of the physics of groundwater flow improves.

I've made up three little introductory groundwater programs in GWBASIC that anyone familiar with programming can put on his home computer. Students who would like copies need only send a self-addressed, stamped envelope to me, care of The Enterprise.

The main program simulates the way a mass of groundwater accumulates in a sandy peninsula when it is rained upon. As time goes on, the water table rises and the deep salt ocean water is displaced. Eventually, after 500 years (a few minutes on the simulator), the groundwater mass reaches an equilibrium size, with water percolating out into the ocean at the same rate as the rainwater addition from on top.

You can change the amount of rain or porosity of the sand. You can also introduce pollutant at the top to see how the plume flows and spreads. You can alter the diffusivity of pollutant in the plume. There are two subsidiary programs that will help you understand the physics of the model and how the main program is set up. I hope that you can get them running on your machine at home.

One of the things that will immediately strike you is that you will need some information about porosity to make real forecasts for the Cape. You will wonder whether porosity is uniform or varies from place to place. You will wonder how anyone can find out. You will want to make versions that allow for periods of drought and periods of excessive precipitation. You will wonder how to incorporate lakes and reservoirs. And you will find yourself launched into scientifically unexplored territory. It is a field that ought to make a good career. 


\section{Some Like It Hot}

T $\mathrm{n}$ the mid-forties the Oceanographic had a fleet of small vessels: an old 1 fishing schooner, the Reliance; the double-ender Anton Dohrn from the vanished marine biological station at Dry Tortugas, and a comfortable little pleasure yacht, the Physalia. They were all pretty small and uncomfortable by today's oceanographic standards, but they won their way into our hearts.

The skipper of the Physalia was an ex-cop from New York City, Ernie Dean. To us youngsters he seemed rather dour. You know how old cops are. The cook was a cheerful spry little man whom we knew as Cappy Lehr. Skipper, cook and boat are all gone now.

These were the days before LORAN. So when the fog rolled in south of Nomans, our navigation was a matter of groping around with fathometer and compass. If we were in the shipping lanes, the big steamers would sometimes pass pretty close. Without radar they didn't know we were there. Capt. Dean would stand musing at the rail, facing into the light moisture-laden breeze, I presumed listening for somebody's foghorn. Our own foghorn was a 20 -inch-long tin whistle that you had to blow by mouth. One gray night, when you couldn't see a boat length, I asked Capt. Dean why we didn't blow our own foghorn. "We will, when we hear another," was his reply.

If Capt. Dean was somewhat gloomy (saturnine might be a better word), the cook Cappy Lehr was by contrast cheerful. The captain was critical about the food and sometimes complained that his breakfast coffee wasn't hot enough. It irked Cappy Lehr.

It was one of those foggy dawns when it seems that your little ship is all alone in the sea. No wind, and you wallow in the troughs, the china clattering in the racks. Ernie woke up grumbling and went on deck to clear his head before sitting down to breakfast.

When he came below, Cappy Lehr surreptitiously extracted a heavy mug from the oven, where he had heated it for half an hour. Holding it with a dishrag, pouring in the steaming coffee, he placed the red-hot mug before the unsuspecting captain. Ernie picked it up, jerked the scalding fluid away from his lips and dropped it back onto the table with the cry: "God! that's hot!" And then, with scarcely a pause, he went on to say, "but just the way I like it." 


\section{The Comet Is Coming}

पalley's Comet is coming and so is the Thanksgiving deadline for our $\Pi$ little contest about the perturbations of the orbit of a comet by Jupiter. The Enterprise raised the prize for the most interesting floppy disk and essay to a total of $\$ 500$, and we hope somebody amongst the youthful scientists hereabouts is taking us seriously.

Those who have been playing around with the problem on their home computers may have already realized that the problem, although old, is also up-to-date. Has anybody noticed that wonderful slingshot effect as the comet, or spaceship, passes close to Jupiter on the side of the sun? Have you thought about introducing a little rocket thrust to adjust the orbit, maybe just to get your comet closer to Jupiter? If you have, you are right in the middle of the most modern things: artificial satellites and, regrettably, even star wars.

The simplest things in science often lead to the most unexpected consequences: for example, there is a big computing project going on right now at M.I.T. to explain how the meteorites that rain upon the earth get diverted from the belt of asteroids into eccentric orbits that bring them close enough to the sun to strike the earth. It has to do with obscure resonances of the repeated perturbations of the asteroids by Jupiter that amplify sufficiently to suddenly disrupt their usually extraterrestrial paths through the sky. Hundreds of hours on big computers are required to reveal these effects, but you can do a lot with your home computer too.

What I hope to convey by offering this prize is the idea that simple ideas, like playing around with cometary orbits, are the gateway to more complicated ideas. Who knows, someday you may be the one who explains the wildly varying rotation of the tiny moon Hyperion or who predicts the arrival of the next giant meteorite that hits the earth.

Oh, by the way, I did ask an authority on Newton how much it cost Halley to have Newton's great work, Principia, published. He couldn't find the exact figures, but estimated around $\$ 100$. So you see, as a late blooming Newton, you ought to find our $\$ 500$ a fair enough prize. But I sincerely hope that you are really writing your programs mostly for the fun of it.

Note: No entries were sent to The Enterprise. 


\section{Henry's Choices}

Some time after the last of the Starbuck essays appeared in The Enterprise, Henry Stommel sent a collection of them to friends and colleagues. Those he chose to send and the pages on which they appear in this volume are:

Recalling Henry Parker .20

On Behalf Of Those Unexpected Discoveries ..........................................21

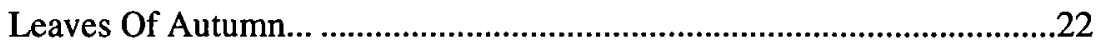

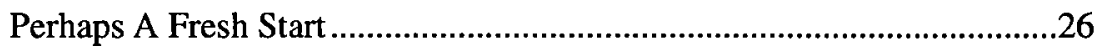

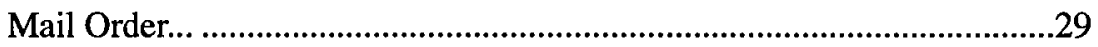

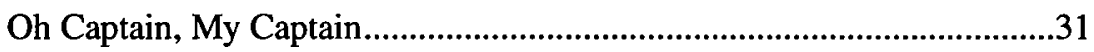

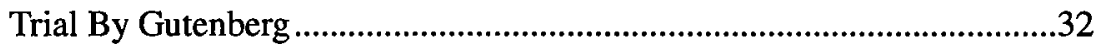

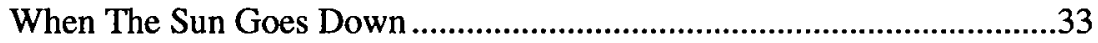

A Man Too Gentle For This World ......................................................34

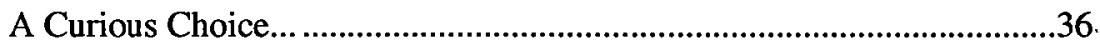

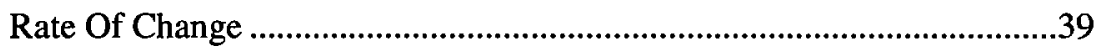

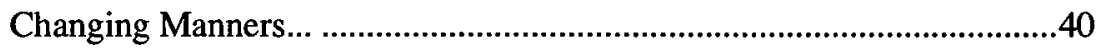

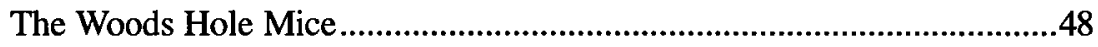

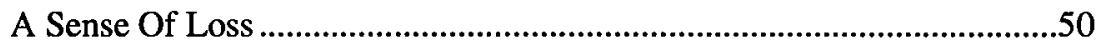

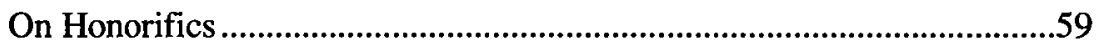

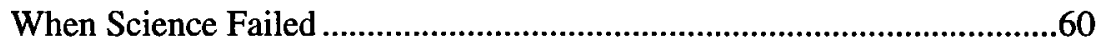

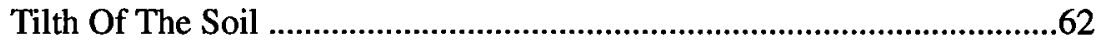

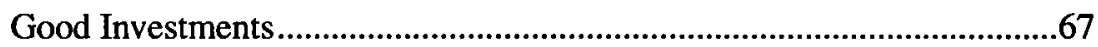

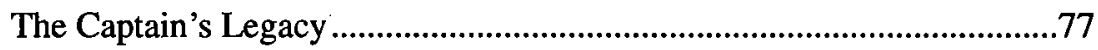

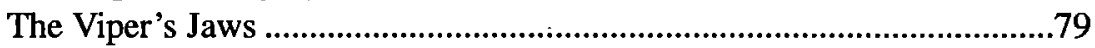

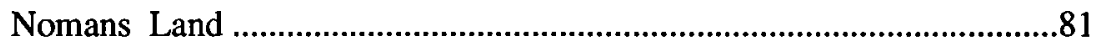

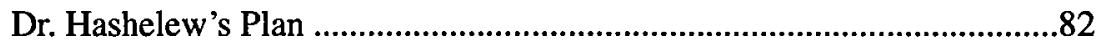

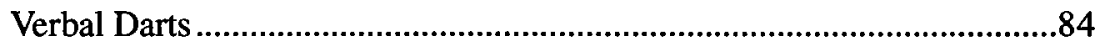

